
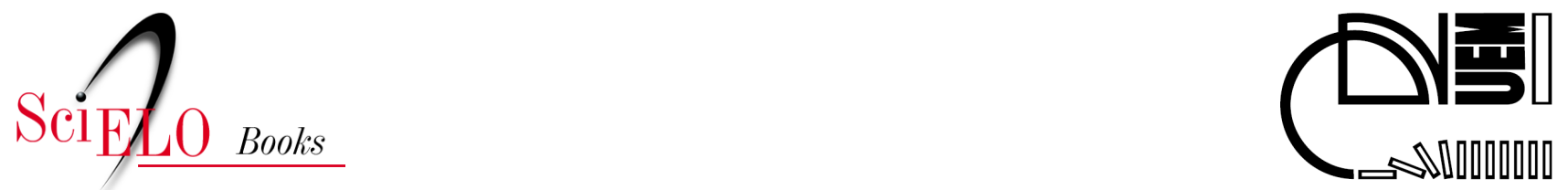

\title{
Capítulo 11 - Principais pragas de hortaliças-fruto nas famílias das Solanáceas, Cucurbitáceas e Fabáceas
}

\author{
Valdenir Catapan \\ Ana Cláudia Buzanini \\ José Maria Matias de Moura \\ Shalene da Silva Santos
}

CATAPAN, V., BUZANINI, A.C., MOURA, J.M.M., and SANTOS, S.S. Principais pragas de hortaliças-fruto nas famílias das Solanáceas, Cucurbitáceas e Fabáceas. In: BRANDÃO FILHO, J.U.T., FREITAS, P.S.L., BERIAN, L.O.S., and GOTO, R., comps. Hortaliças-fruto [online]. Maringá: EDUEM, 2018, pp. 357-386. ISBN: 978-65-86383-01-0. https://doi.org/10.7476/9786586383010.0013.

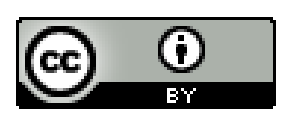

All the contents of this work, except where otherwise noted, is licensed under a Creative Commons Attribution 4.0 International license.

Todo o conteúdo deste trabalho, exceto quando houver ressalva, é publicado sob a licença $\underline{\text { Creative Commons }}$ Atribição 4.0. 


\section{Principais pragas de hortaliças-fruto nas famílias das Solanáceas, Cucurbitáceas e Fabáceas}

Valdenir Catapan, Ana Cláudia Buzanini, José Maria Matias de Moura e Shalene da Silva Santos

\section{Introdução}

A horticultura é uma atividade agroeconômica realizada por micros, pequenas, médias e grandes propriedades, localizadas tanto no interior, quanto nas proximidades dos grandes centros e, nos últimos anos, nos centros urbanos. As hortaliças produzidas em campo aberto exigem investimento médio inicial alto, sendo grande parte desse investimento direcionado ao controle de pragas.

$\mathrm{Na}$ horticultura, as pragas encontram hospedeiros em abundância durante todo o ano, muitas vezes espécies da mesma família ou a mesma espécie sendo produzida em ciclos sucessivos como ocorre com a cultura do tomate, e essas, muitas vezes, em diferentes estádios fenológicos para que a continuidade da produção seja garantida durante o ano. A continuidade e a sucessão da cultura possibilitam a sobrevivência dos insetos-praga, gerando a necessidade de controle contínuo para que o ataque não cause prejuízos além do investimento.

Assim como em culturas como soja e milho, o Manejo Integrado de Pragas (MIP) é de fundamental importância para o controle de pragas na horticultura, pois trabalha com a integração de diferentes ferramentas de controle, tais como os produtos químicos, agentes biológicos e técnicas de controle cultural, com o objetivo de diminuir as chances de os insetos-praga se adaptarem a alguma prática defensiva em especial.

O MIP não visa eliminar os agentes (insetos-praga), mas sim reduzir sua população de modo a permitir que seus inimigos naturais permaneçam no local onde a cultura será implantada e assim restabelecer o equilíbrio dentro do possível.

Um inseto é considerado praga quando ele reduz a produção das culturas ao atacá-las; quando são transmissores de doenças (principalmente viroses) ou quando interferem na qualidade dos produtos agrícolas, inviabilizando sua comercialização. No sistema do MIP, a simples constatação da presença da praga na lavoura não corresponde ao início da aplicação de métodos de controle. Do ponto de vista do manejo integrado de pragas, esse inseto, ao se alimentar de uma planta cultivada, provoca nela uma injúria que é definida como qualquer alteração deletéria decorrente de sua ação. A planta injuriada perde produção, que pode ser quantificada monetariamente, recebendo o nome de Dano Econômico. A dúvida é saber quando esse dano se torna significativo e, para isso, foi criado o conceito de Nível de Dano Econômico (NDE), que é a densidade populacional de uma praga capaz de causar prejuízo de igual valor ao seu custo de controle.

A tomada de decisão de controle deve levar em consideração não só o Nível de Dano Econômico, mas também a densidade populacional dos inimigos naturais, o estádio em que as plantas se encontram e se as condições climáticas estão favoráveis ao desenvolvimento da praga. 
Após a identificação, a quantificação da praga e os demais fatores citados acima, deve-se tomar a decisão de quais métodos de controle serão empregados. Dentre as técnicas de controle usual recomendadas do Manejo Integrado de Praga estão:

Uso de variedades resistentes - Algumas variedades de plantas foram melhoradas e desenvolveram mecanismos de defesa, tornando-se resistentes ou tolerantes, repelentes ou menos preferidas pelas pragas. As vantagens desta técnica incluem facilidade de uso, compatibilidade com outras táticas de controle de pragas e impacto cumulativo sobre a praga com mínimo impacto ambiental.

Controle através de práticas agrícolas - A adoção de certas práticas agrícolas torna o plantio menos favorável às infestações, como rotação de culturas com espécies diferentes, destruição de restos culturais, seleção de áreas de plantio com baixo histórico de ataque, plantio de culturas-armadilhas e ajuste do plantio e da colheita na época menos favorável às infestações.

Controle através do manejo da nutrição - Realizar adubação conforme a análise química do solo ou foliar e requerimento da cultura, evitando assim a deficiência ou o excesso de nutrientes, em especial o nitrogênio $(\mathrm{N})$. O excesso de $\mathrm{N}$ geralmente proporciona maior conteúdo de aminoácidos livres e açúcares na planta, bem como a existência de tecidos mais tenros, favorecendo principalmente o ataque de insetos sugadores, tais como mosca-branca e pulgões. Esses aminoácidos e açúcares aceleram o desenvolvimento dos insetos e aumentam sua taxa reprodutiva, e têm como consequência o aumento da população e da intensidade de ataque.

Controle físico e mecânico - O uso de coberturas do solo entre as plantas é uma forma de mudar o campo visual dos insetos e causar repelência. No período diurno, a utilização de superfícies refletivas, como o uso de cobertura com filme plástico (mulching) e o uso de palha de arroz que refletem as radiações na faixa azul e ultravioleta, causa repelência a pulgões. Outras técnicas apropriadas incluem o uso de armadilhas plásticas com cores atrativas a espécie, fitas adesivas coloridas e armadilha luminosa com lâmpada fluorescente como forma de atrair insetos noturnos.

Biocontrole (ou controle biológico) - Entende-se como o uso de produtos químicos que ocorrem naturalmente ou de organismos benéficos para prevenir, reduzir ou erradicar a infestação de pragas e doenças nas plantas. No caso dos insetos-praga, busca-se atrair ou introduzir inimigos naturais da praga, os quais podem ser insetos, vírus, fungos ou bactérias, que atuam como predadores, parasitas e agentes patogênicos. A vantagem em utilizar o biocontrole está relacionada com a redução de acidentes ambientais e com a segurança pública. Por outro lado, as principais desvantagens estão relacionadas com a necessidade de um melhor planejamento na gestão do manejo da cultura, podendo levar mais tempo e, às vezes, os custos podem ser superiores ao uso de defensivos agrícolas químicos, requerendo um sistema de acompanhamento e treinamento.

Controle químico - Sob a ótica do MIP, somente quando as técnicas anteriores se mostraram ineficazes para controlar a infestação da praga, então o uso de defensivos agrícolas se torna justificável. Em muitas culturas, os inseticidas ainda são os principais meios de controle de pragas e apresentam suas vantagens: são relativamente baratos e fáceis de aplicar, de transportar e são versáteis, pois podem ser apresentados em diferentes formas, tais como pós, aerossóis, líquidos, granulados, iscas e de liberação lenta.

Dentre as três famílias consideradas neste capítulo, estão culturas de grande importância, como tomate representando as Solanáceas, pepino e melão representando as Cucurbitáceas e feijão-devagem dentro da família das Fabáceas. Entre essas culturas, há pragas em comum, como as pragas polífagas que são de grande importância devido aos danos diretos e indiretos.

Neste capítulo, inicialmente, serão descritas as pragas que atacam pelo menos duas dessas famílias e, posteriormente, pragas de importância econômica de cada família especificamente. 


\section{Pragas polífagas}

\subsection{Mosca-branca (Complexo Bemisia tabaci) - Hemiptera: Aleyrodidae}

Mosca-branca é um inseto cosmopolita e amplamente distribuído no mundo, tem hábito sugador e de grande importância econômica em diversas culturas de famílias como Fabaceae, Cucurbitaceae, Malvaceae e Solanaceae.

O complexo de espécies denominadas como mosca-branca compreende mais de 1.450 espécies descritas em todo o mundo, sendo a Bemisia tabacia espécie mais popular devido à sua população elevada e, consequentemente, aos prejuízos causados, assim como em Bemisia tabaci, há biótipos ou raças, sendo o de maior importância como praga o biótipo $\mathrm{B}$.

O biótipo B se tornou popular no Brasil após surtos no início da década de 90 no Estado de São Paulo, de onde rapidamente se espalhou pelas principais fronteiras agrícolas do país, o que acabou resultando no deslocamento do biótipo $\mathrm{A}$, anteriormente presente nessas áreas.

Bemisia tabaci biótipo B apresenta uma taxa de reprodução cerca de $30 \%$ superior ao biótipo A, é mais tolerante ao frio; possui maior gama de hospedeiros, maior capacidade de excretar açúcares, também chamado de honeydew, maior capacidade de indução de anomalias fisiológicas através da transmissão de viroses, além de maior resistência aos inseticidas.

O ciclo biológico da mosca-branca é dividido em ovo, quatro ínstares ninfais e adultos. Os ovos possuem formato alongado, tamanho de $0,2 \mathrm{~mm}$, com pedúnculo de cor branco-amarelado passando a marrom-escuro ao final do período de 5 a 8 dias. São postos na face abaxial das folhas mais jovens, com pilosidade moderada, para que fiquem protegidos dos ventos e dessecação. Eclodindo os ovos, as ninfas passam a sugar a folha, geralmente na face inferior, as quais, no primeiro ínstar, são móveis por alguns minutos, até localizar local adequado na planta para se fixar.

As ninfas do primeiro, do segundo e do terceiro ínstar são transparentes, de formato oval, medindo $0,3 \mathrm{~mm}, 0,4 \mathrm{~mm}$ e $0,5 \mathrm{~mm}$, respectivamente, sendo que, a partir do segundo ínstar, são sésseis. O quarto ínstar é dividido em três fases. Inicialmente, a ninfa é achatada, translúcida, com apêndices rudimentares. Posteriormente, na segunda fase, torna-se opaca e cerosa, medindo aproximadamente $0,6 \mathrm{~mm}$, e, na terceira e última fase, torna-se amarelo-esbranquiçada semelhante ao adulto.

Os adultos são insetos pequenos de $1 \mathrm{~mm}$ de comprimento, com quatro asas membranosas recobertas por uma pulverulência branca, sendo a fêmea ligeiramente maior que o macho, com capacidade de depositar de 100 a 300 ovos durante todo seu ciclo de vida, dependendo da alimentação e da temperatura.

O ciclo dura em temperaturas entre $25{ }^{\circ} \mathrm{C}$ e $27{ }^{\circ} \mathrm{C}$, de 16 a 25 dias, de acordo com a planta hospedeira e com as condições ambientais, sendo em média oito dias para o período de incubação e de 12 a 21 dias para a fase ninfal. A temperatura ideal está na faixa de $25^{\circ} \mathrm{C}$ a $30^{\circ} \mathrm{C}$.

Os danos diretos causados pela mosca-branca em tomate são devido à sua alimentação, na qual realiza a sucção da seiva e injeta substâncias tóxicas. Com isso, há redução no vigor das plantas atacadas, indução de anomalias fisiológicas, como a isoporização da polpa e de uniformidade da maturação dos frutos do tomateiro. Há também a excreção do chamado honeydew (melado) sobre as folhas, rico em açúcares que serve de substrato para o desenvolvimento do fungo fumagina (Capnodium spp., Capnodiaceae), capaz de afetar a fotossíntese, pois prejudica a capacidade de a luz solar atingir a superfície foliar.

Em cucurbitáceas como a melancia, essa praga, além dos danos pela excreção do honeydew e consequentemente formação da fumagina, em alta população, pode causar o amarelecimento de folhas mais velhas e o secamento das folhas em plantas jovens, levandoà morte das plantas. 
Durante a alimentação, há a inoculação de toxinas que podem causar alterações no desenvolvimento vegetativo e reprodutivo das plantas.

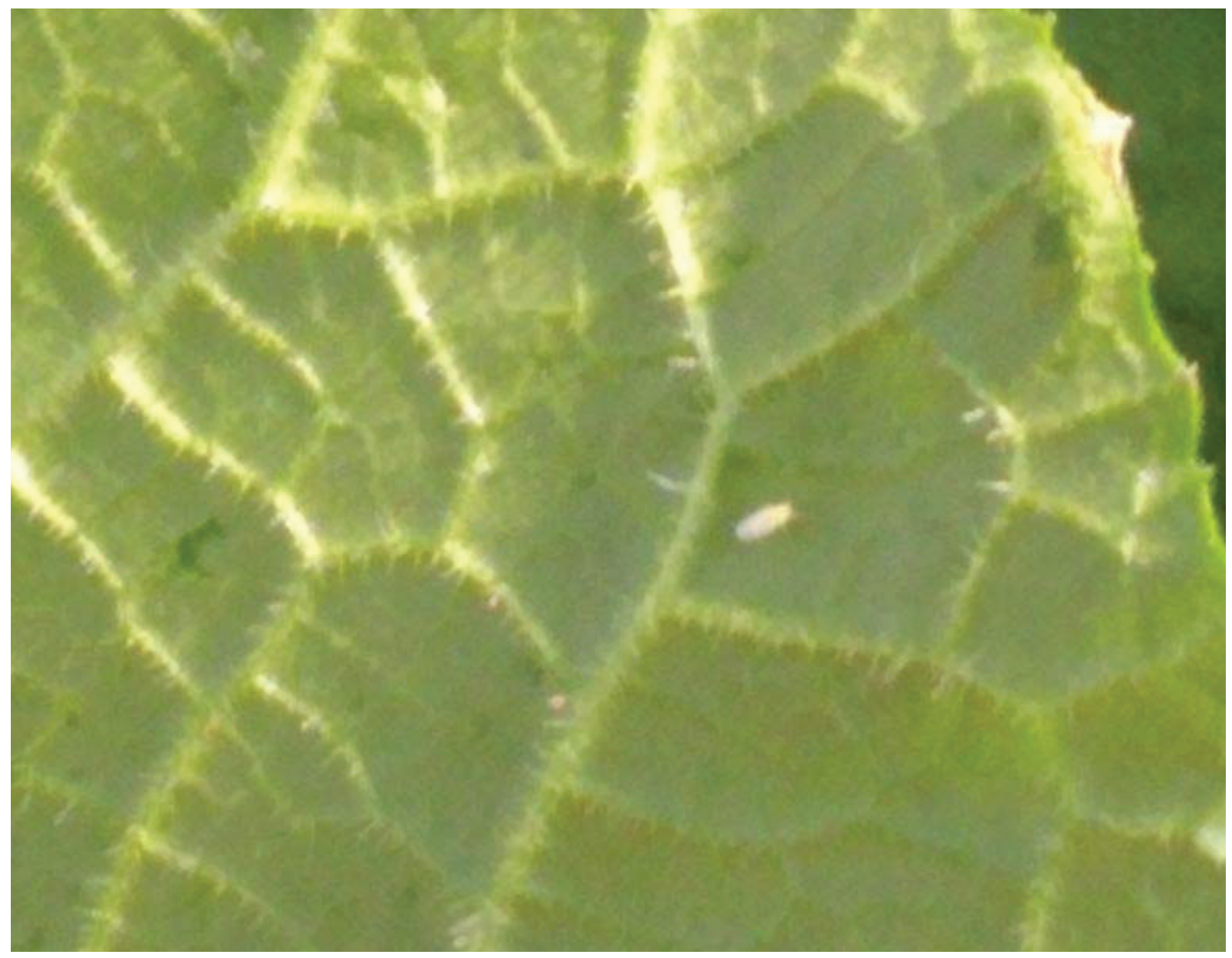

Figura 1 - Bemisia tabaci biótipo B na cultura do pepino.

Fonte: Os autores.

Em relação ao controle, a primeira ação a ser tomada é a compra de mudas sadias e vigorosas, com certificado de sanidade, produzidas em viveiros com estrutura necessária para que não ocorra a presença da praga até que essas mudas cheguem ao produtor.

$\mathrm{Na}$ área em que mudas serão transplantadas, deve-se atentar para que não haja plantas daninhas hospedeiras da mosca-branca,como amendoim-bravo (Euphorbia heterophylla), ervade-santa-maria (Chenopodium ambrosioides), fedegoso (Senna obtusifolia), guanxuma-rasteira (Sida urens), maria-pretinha (Solanum americanum), mentruz (Lepidium virginicum), perpétuabrava (Gomphrena celosioides) e poaia-do-cerrado (Richardia scabra); também devem-se eliminar restos culturais que permaneceram na área após o final da colheita para erradicar a população remanescente.

Para monitoramento e poder de decisão da entrada do controle químico, o uso de armadilha de cor amarela é recomendado antes do transplante e durante o cultivo. Antes do transplante,as armadilhas devem ser dispostas em torno da área de cultivo, e caso a presença de adultos seja constatada, a realização do controle deve ser feita logo após o fim do período de proteção do produto aplicado nas mudas. O controle após o período de transplante deve obedecer ao nível de dano econômico de 1 adulto por planta, devido à sua capacidade de transmissão de viroses. 
Há muitos defensivos agrícolas registrados para o seu controle, entretanto o uso indiscriminado desses, em décadas passadas, colaborou para o desenvolvimento de resistência a diversos princípios ativos, como organofosforados, piretroides, hidrocarbonetos clorados. Portanto o uso das novas moléculas que vêm sendo registradas para o controle de mosca-branca deve ser realizado de maneira responsável e em adição a outras técnicas de manejo.

\subsection{Tripes (Thysanoptera: Thripidae)}

Já foram identificadas 6.018 espécies de tripes em diferentes regiões do mundo, divididos em 9 famílias, 8 pertencentes à subordem Terebrantia e uma família pertencente à subordem Tubulifera. A subordem Terebrantia é constituída por 2.400 espécies, sendo que a família Thripidae, pertencente à esta subordem, possui quase 2.100 espécies registradas. A subordem Tubulifera é composta por uma grande família, a Phlaeothripidae, a qual é constituída por 3.500 espécies descritas.

No Brasil, já foram identificadas 545 espécies de tripes, das quais em torno de 24 espécies são consideradas causadoras de danos de forma direta e/ou indireta para as diversas plantas cultivadas, sendo 22 dessas espécies da subordem Terebrantia; contudo não são todas as espécies que causam prejuízos econômicos para a agricultura.

Como acontece com os afídeos, as espécies de tripes consideradas pragas podem causar danos diretos e indiretos às culturas. Os danos diretos são decorrentes da alimentação das ninfas e dos adultos nos tecidos vegetais, causando o aparecimento de pontos prateados nas superfícies das folhas e das flores, como também o surgimento de estrias. Como resultado do ataque, as folhas apresentam alteração em sua consistência, ficando coriáceas e quebradiças e também podem causar o abortamento de flores. Nos frutos, o ataque pode causar abortamento, deformação ou ferimentos que alterarão a qualidade final. Indiretamente, os tripes causam grandes prejuízos, agindo como agentes vetores na transmissão de viroses em culturas de importância econômica na horticultura.

\section{Frankliniella schultzei (Trybom, 1910)}

Esta espécie apresenta diferentes cores, variando de marrom-claro a marrom-escuro; as fêmeas adultas medem em torno de 1,4 $\mathrm{mm}$ de comprimento e os machos cerca de 1,0 $\mathrm{mm}$. As fêmeas ovopositam os seus ovos no interior do tecido epidérmico da folha. Em temperatura de $24,5{ }^{\circ} \mathrm{C}$, esses adultos têm uma longevidade de aproximadamente 13 dias e o ciclo de vida para uma geração completa em cerca de 12,6 dias.

Os tripes apresentam reprodução sexuada e partenogênese, sendo que a metamorfose é incompleta com dois estágios larvais, um estágio de pré-pupa e outro de pupa, antes do estágio adulto. Nos dois primeiros ínstares larvais, essas se assemelham aos adultos na aparência, exceto pela ausência das asas, por apresentarem olhos pigmentados de vermelho e menor número de antenômeros. São caracteristicamente ativas, alimentando-se constantemente.

Seguem-se dois períodos em que não ocorre alimentação: na fase de pré-pupa e de pupa. $\mathrm{O}$ período de pré-pupa é de inatividade, embora seja capaz de andar se perturbada. As antenas são curtas, posicionadas para frente da cabeça e as tecas alares aparecem relativamente curtas. $\mathrm{O}$ período de pupa caracteriza-se pelas antenas posicionadas atrás da cabeça, para baixo, pelas tecas alares mais alongadas e pela total inatividade alimentar e de movimento.

\section{Thripspalmi (Karny)}

Esta espécie está presente em diversos países, principalmente nos de clima tropical, com potencial de infestações elevadas em ambientes de cultivo protegido. Os adultos de T. palmi são de cor amarelo-claro ou esbranquiçado, apresentam uma linha preta na área de junção das asas. 0 tamanho varia de $0,8 \mathrm{~mm}$ a $1,0 \mathrm{~mm}$ de comprimento, sendo as fêmeas geralmente maiores que os machos, com uma longevidade de 10 a 30 dias contra 7 a 20 dias nos machos. 
As fêmeas ovopositam no interior do tecido das folhas e a coloração dos ovos vão de incolores a uma cor esbranquiçada, em forma de grão de feijão. Em temperaturas de $15{ }^{\circ} \mathrm{C}$, apresentam longevidade média de 16 dias, 7,5 dias em $26^{\circ} \mathrm{C}$ e 4,3 dias quando a temperatura chega a $32^{\circ} \mathrm{C}$. As larvas se assemelham aos adultos em relação à forma do corpo e à coloração, sendo a diferença entre as duas fases a presença de asas na fase adulta. As larvas alimentam-se junto aos adultos, especificamente nas nervuras das folhas, mas também podem estar próximas aos pontos de crescimento dos ramos, entre as pétalas, nos brotos em desenvolvimento e na superfície dos frutos.

\section{Caliothrips phaseoli}

Esta é uma espécie de tripes de grande importância na cultura do feijão-de-vagem, sendo observada também em cucurbitáceas como o pepino, principalmente em épocas de seca e baixa umidade relativa do ar. As plantas atacadas apresentam manchas prateadas no limbo e as bordas dobradas, voltadas para cima. Os folíolos atacados apresentam estrias e deformações, ocorrendo desfolha em alguns casos devido à necrose dos tecidos atacados.

$O$ adulto de Caliothrips phaseoli vive por aproximadamente 15 dias emede cerca de 1,0 $\mathrm{mm}$ de comprimento. Apresenta coloração preta, com duas faixas brancas nas asas franjadas, as pernas são marrom-escuras com extremidades amarelas e, no estágio imaturo, são de coloração amarelada.

As fêmeas inserem os ovos nas folhas, nos pecíolos e no caule, e os ovos eclodem em cinco ou seis dias. A larva tem coloração branco-amarelada e, no primeiro ínstar, desenvolvem-se de um a dois dias. O segundo ínstar dura de quatro a cinco dias. A fase de pré-pupa e de pupa acontece no solo entre dois a quatro dias.
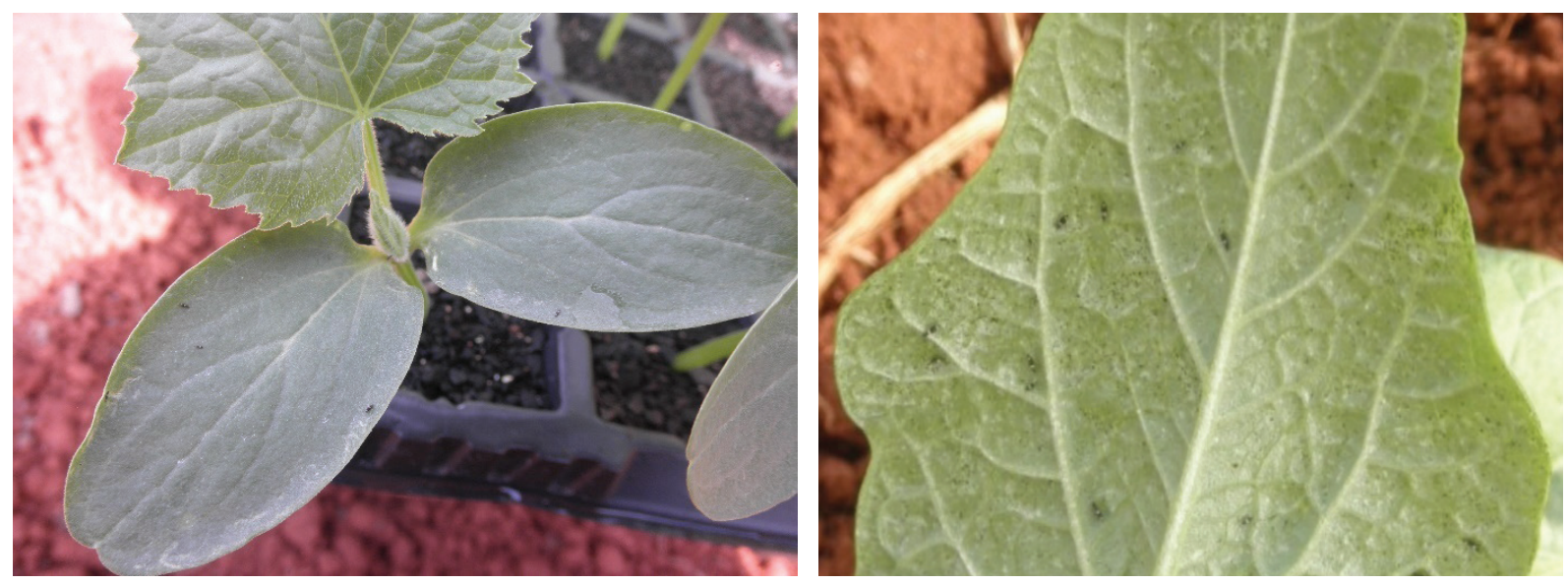

Figura 2 - Caliothrips phaseoli na cultura do feijão-de-vagem (esquerda) e na cultura do pepino ainda em fase de muda (direita).

Fonte: Os autores.

O controle cultural para os tripes é similar aos utilizados para o controle de pulgóes, ou seja, deve-se priorizar a aquisição de mudas sadias de viveiros certificados, previamente protegidas do ataque de pragas, bem como procurar cultivares resistentes a principais viroses que estes podem transmitir. Em relação à área de cultivo, a eliminação de restos culturais e de plantas daninhas e o uso de quebra-ventos ao redor da área de cultivo são essenciais.

Para o monitoramento de adultos de tripes, é indicado o uso de armadilhas adesivas de coloração azul, posicionadas na altura do topo das plantas com auxílio de estacas. Caso não sejam implantadas as armadilhas, deve-se realizar, a cada dois ou três dias, a batedura dos ponteiros, que consiste em agitar vigorosamente as folhas da região superior das plantas em uma bandeja branca, onde, em cada ponto de amostragem, deve-se agitar uma planta e avaliar a quantidade de insetos presentes, 
assim como a identificação. Para ambos os métodos, as observações devem ser realizadas nos primeiros 60 dias após o transplante das plantas.

O controle biológico pode ser realizado por meio de larvas de Syrphidae, de larvas de Crisopideos (bicho-lixeiro), de alguns coleópteros (joaninhas), de tripes predadores dos gêneros Scolothrips e Franklinothrips e de percevejos do gênero Orius. O controle biológico, para conseguir eficiência, deve ser realizado em baixas populações das pragas, associado a inseticidas seletivos.

Outra forma de controle é o químico, com uso de inseticidas. Existem alguns ingredientes ativos registrados, como Tiametoxam, Acetamiprido e Imidacloprido. Esses devem ser aplicados a partir do monitoramento e da constatação da praga e de sua identificação, assim como seu nível de controle.

\subsection{Pulgões}

Os pulgões são pragas polífagas, ou seja, atacam diversas famílias de plantas, entre elas Cucurbitaceae, Malvaceae, Solanaceae e Rutaceae, e estão presentes em regiões de clima tropical, subtropical e temperado. Esses afídeos podem causar danos diretos, como a extração de carboidratos e de aminoácidos do floema das plantas, e indiretamente podem transmitir mais de 100 espécies de vírus fitopatogênicos, responsáveis por grandes prejuízos na agricultura.

\section{Pulgão verde - Myzus persicae}

O pulgão verde é um afídeo de ampla distribuição mundial em hortícolas de importância econômica, sejam essas produzidas em campo ou em ambientes de cultivo protegido.

Os adultos desta espécie podem ser alados ou ápteros, sendo os alados caracterizados por um abdômen verde-amarelado, cabeça e tórax pretos e sifúnculos escurecidos no ápice, com tamanho de até 2,0 $\mathrm{mm}$ de comprimento. Essa forma é responsável pela disseminação de vírus na lavoura devido à sua alta mobilidade. Os pulgões adultos ápteros têm cerca de 2,0 $\mathrm{mm}$ de comprimento, cor amarelada ou esverdeada, podendo apresentar listras verdes mediais e laterais.

Os ovos de Myzus persicae tem 0,6 $\mathrm{mm}$ de comprimento e 0,3 $\mathrm{mm}$ de largura em um formato elíptico, sendo inicialmente amarelos ou verdes e, posteriormente, tornam-se pretos. As ninfas inicialmente apresentam coloração esverdeada, que evolui para amarelada, sendo muito parecidas com os adultos ápteros.

O seu ciclo de vida, em condições ideais, pode levar de 8 a 10 dias, o que contribui para uma população significativamente alta em poucos dias. Nessa espécie de pulgão, é comum não ocorrer a produção de ovos, pois as fêmeas dão origem a ninfas via partenogênese, podendo haver até 20 gerações. É conhecido que, a partir da oitava geração, ocorra a produção das fêmeas aladas em consequência da possível escassez de alimento, assim as fêmeas aladas podem migrar para outras plantas e dar origem a novas fêmeas ápteras em novos hospedeiros. Em países em que o inverno é rigoroso, com temperaturas abaixo de $4{ }^{\circ} \mathrm{C}$, além das fêmeas aladas, também há a presença de machos. As fêmeas aladas produzem fêmeas ápteras em plantas hospedeiras que sobrevirão ao inverno, tais como repolho e batata, estas produzem feromônios que atrairão os machos que as fecundarão e assim haverá produção de ovos.

\section{Pulgão-do-algodoeiro - Aphis gossypi}

O pulgão Aphis gossypi, conhecido popularmente no Brasil como pulgão-do-algodoeiro ou pulgão-do-meloeiro, apresenta alta capacidade de reprodução, bem como alta gama de hospedeiros, o que favorece sua presença nas culturas de importância econômica, principalmente em áreas de cultivo contínuo.

A reprodução dessa espécie em regiões tropicais ocorre unicamente via partenogênese, ou seja, as fêmeas dão origem a novas fêmeas de maneira assexual. Sendo assim, a população é constituída 
de ninfas e de fêmeas adultas ápteras vivíparas, não produzindo ovos, gerando diretamente as ninfas em número de 4 a 5 por dia em condições de $25^{\circ} \mathrm{C}-27^{\circ} \mathrm{C}$, com o ciclo de vida da espécie em média de 10 dias. Quando as condições climáticas deixam de ser ideais, há um aumento significativo da população, causando uma competição intraespecífica, e ocorre a produção de fêmeas aladas.

As fêmeas adultas ápteras têm tamanho de $0,9 \mathrm{~mm}$ a $1,8 \mathrm{~mm}$ de comprimento e apresentam policromismo, ou seja, a sua coloração é variável de verde-escuro ao amarelo-claro, conforme a sua fonte de alimentação, densidade populacional e temperatura do ambiente. A forma alada mede entre $1,1 \mathrm{~mm}$ e $1,8 \mathrm{~mm}$ de comprimento, cabeça e tórax preto e abdômen esverdeado. As ninfas variam de coloração de marrom-claro ao cinza, com cabeça e tórax mais escuros que o restante do corpo.

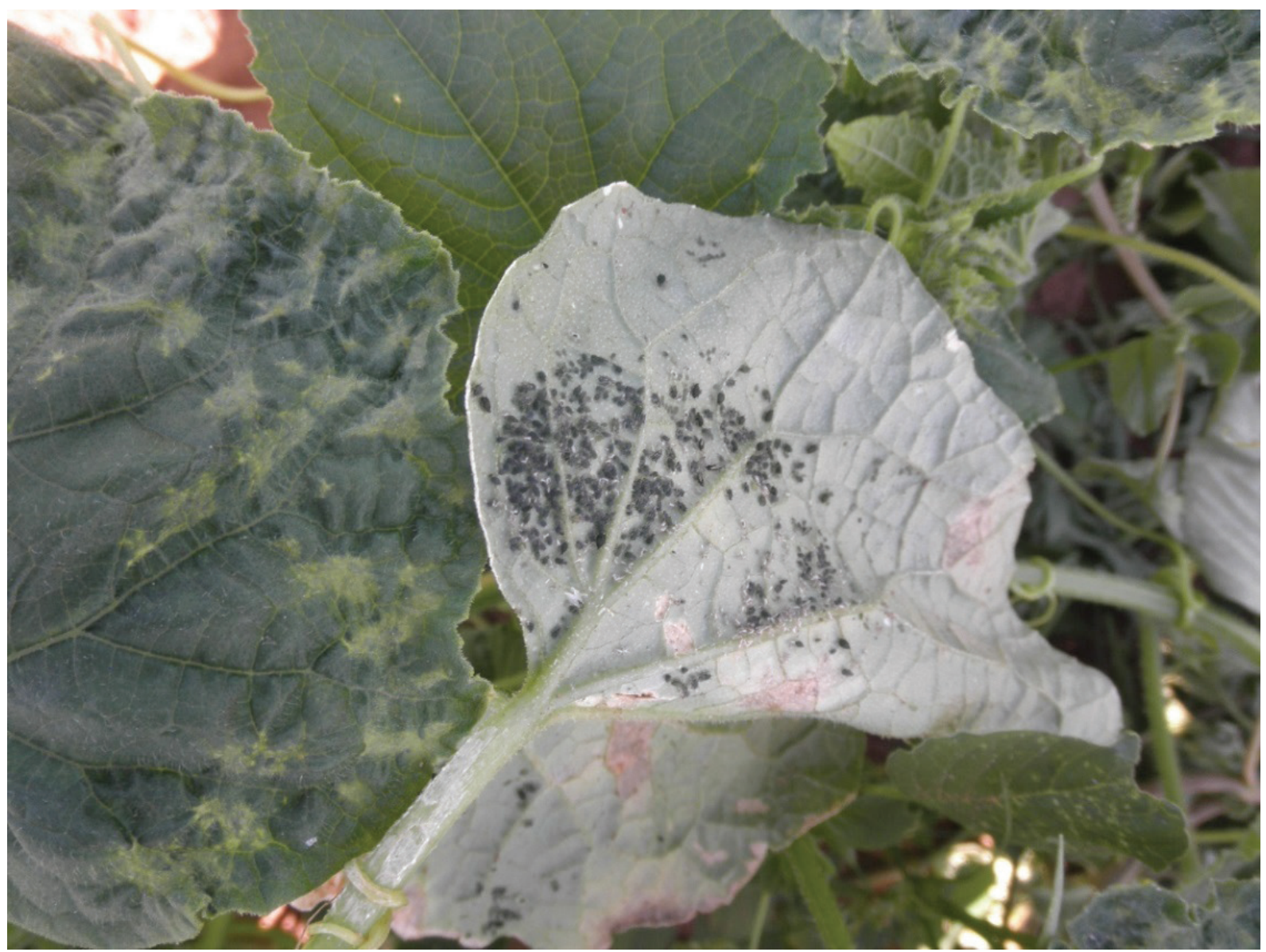

Figura 3 - Aphis gossypi na cultura do pepino.

Fonte: Os autores.

O controle de pulgões deve ser um conjunto entre controle cultural, químico e biológico. Inicialmente, deve-se realizar o controle cultural adquirindo sementes e/ou mudas certificadas, erradicar as plantas daninhas na área de cultivo, evitando assim hospedeiros alternativos aos pulgões, e evitar plantio de culturas hospedeiras próximo à área de cultivo.

Essa praga é favorecida pelo clima quente e seco, e ambientes de cultivo protegido podem apresentar altas populações em curto período de tempo.O monitoramento da presença da praga através de armadilhas ou batedura de ponteiros é essencial para um controle efetivo. As armadilhas utilizadas para monitorar população de pulgões podem ser cartolinas, lonas, plásticos ou etiquetas, de coloração amarela, untadas com óleo (vegetal ou mineral) ou cola entomológica, posicionadas na 
altura das plantas. Em relação à batedura de ponteiros, utiliza-se a mesma técnica utilizada para determinar população de tripes.

O uso de controle químico para esses afídeos é indicado a partir do momento em que há constatação de um adulto por planta ou por armadilha, devido à sua capacidade de transmissão de viroses. A aplicação de inseticidas deve ser realizada de modo que se consiga atingir os pulgões na face abaxial das folhas, bem como nas áreas onde as folhas estão retorcidas e encarquilhadas devido às toxinas liberadas pelos pulgões. Portanto, pensando em um controle efetivo, o uso de inseticidas sistêmicos é o mais recomendado, pois, com a utilização de inseticidas de contato, há maior dificuldade de atingir esses insetos devido à sua localização.

\subsection{Mosca-minadora - Liriomyza spp. (Guenee, 1854)}

Estes insetos, pertencentes a família Agromyzidae, estão distribuídos em todo o mundo, desde o Norte da Groelândia até as ilhas subantárticas no Sul da Nova Zelândia. O gênero Liriomyza é composto por 376 espécies, e as moscas-minadoras do gênero Liriomyza são mais comuns em áreas temperadas, com poucas espécies nos trópicos.

Dentre as cinco espécies consideradas polífagas, Liriomyza bryoniae e Liriomyza strigata são nativas da Europa, enquanto Liriomyza trifolii, Liriomyza sativae e Liriomyza huidobrensis são originárias das Américas. Estas três últimas espécies citadas têm causado muita preocupação atualmente, em razão de sua ampla polifagia e do aumento da sua ocorrência em novas áreas geográficas. Sabe-se que L. Trifolii está presente em 97 países, L. huidobrensis em 63 e L. sativae em 54 países.

O raio de dispersão natural de $L$. trifoliise estende dos estados no Nordeste dos Estados Unidos até o Golfo do México, sendo a Flórida (EUA) o centro de origem da praga.Na América do Sul, também há registros de L. trifoliina Guiana Francesa, na Guiana, no Peru, no Equador, no Chile, no Brasil e na Argentina.

No Brasil, estas três espécies (L. huidobrensis (Blanchard), L. sativae (Blanchard) e L. trifolii (Burgess) ocorrem naturalmente em quase todos os estados, atacando mais de 25 famílias de plantas.

As moscas-minadoras do gênero Liriomyza são consideradas as de maior importância econômica do grupo. Uma grande diversidade de culturas, principalmente de oleráceas e plantas ornamentais, está associada à ocorrência desses dípteros, em campo e em cultivos protegidos. As plantas espontâneas são também hospedeiras comuns desses insetos-praga.

Os adultos de Liriomyza spp. são moscas de tamanho reduzido, com aproximadamente $2 \mathrm{~mm}$ de comprimento, de coloração escura, apresentando manchas amareladas no tórax e na face superior da cabeça. As asas utilizadas para o voo são transparentes e se dispersam durante o dia. As fêmeas podem viver cerca de 26 dias, nos quais chegam a depositar de 500 a 700 ovos. Elas ainda fazem dois tipos de puncturas com seu ovopositor nas folhas, onde um quinto são feitas para a ovoposição, enquanto o restante para alimentar-se do líquido extravasado.

O acasalamento ocorre 24 horas após a emergência dos adultos, nas primeiras horas da manhã; os machos e as fêmeas podem acasalar-se mais de uma vez, estratégia utilizada pela espécie para uma produção máxima de ovos. A postura dos ovos é realizada isolada e endofiticamente (no interior das folhas), e a postura pode ser feita tanto na face adaxial quanto abaxial das folhas. O período para o desenvolvimento do ovo para a fase de larva pode levar de 2 a 3 dias.

Logo após a eclosão dos ovos, as larvas iniciam sua alimentação e continuam até atingir seu completo desenvolvimento, correspondendo a fase larval a aproximadamente 5 dias, passando por 3 ínstares. Dependendo da espécie de Liriomyza spp., o local de alimentação pode diferir: L. trifolli tem preferência pelo mesofilo paliçádico; L. huidobrensis, pelo mesofilo esponjoso; L. brasicae pelo mesofilo paliçádico e esponjoso; assim como podem atacar outras estruturas das plantas, dependendo da disponibilidade de alimento. 
A fase de pré-pupa pode ser verificada quando a larva para de se alimentar e elimina suas excreções. Ao sair da folha, inicia a fase de pupa no solo próximo ao caule, ou eventualmente na folha ou na sua base. Essa fase pode ser considerada a responsável por cerca de $50 \%$ do período entre ovo e adultos de Liriomyza spp., podendo chegar a 9 dias dependendo da temperatura.

O ciclo de vida total de Liriomyza spp., do ovo à fase adulta, pode variar de 12 a 51 dias, entre as temperaturas de $32^{\circ} \mathrm{C}$ e $15^{\circ} \mathrm{C}$, respectivamente.
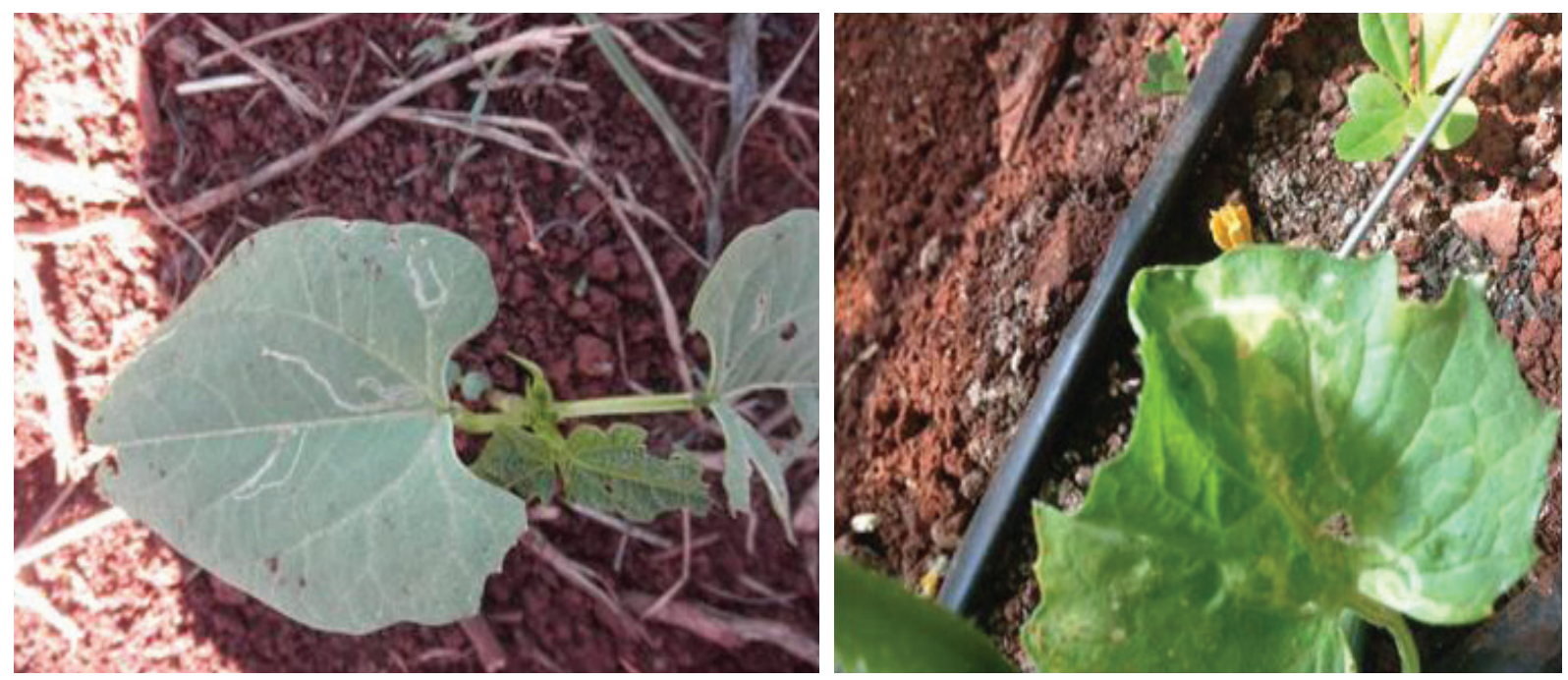

Figura 4 - Ataque de larva-minadora em feijão (esquerda) e em pepino (direita).

Fonte: Os autores.

É na fase larval que ocorrem os danos associados a essa praga. As larvas formam galerias (minas) irregulares, translúcidas de coloração amarelada nas folhas, destruindo o parênquima foliar, fazendo que a folha seque, reduzindo a capacidade fotossintética da planta, o que afeta diretamente a qualidade dos frutos. O sentido e a orientação das galerias são aleatórios, de forma irregular e, algumas vezes, apresentam ramificações. As minas atuam também como porta de entrada para patógenos, como fungos e bactérias, prejudicando ainda mais o desenvolvimento das plantas.

Inicialmente,o manejo dessa praga envolve o controle cultural. Esse tipo de controle busca transformar o ambiente agrícola e torná-lo impróprio ao desenvolvimento da praga, seja reduzindo seu potencial de colonização, promovendo sua dispersão ou dificultando sua reprodução e deve ser iniciado antes mesmo da instalação da cultura, observando-se o histórico de presença e ataque da praga na área. Dentre as práticas utilizadas, podemos citar a eliminação de restos culturais, a eliminação de plantas daninhas e hospedeiras, a rotação de culturas, a utilização de plantas-iscas ao redor da cultura (o plantio de girassol), o pousio (manter a área sem plantio por um determinado período) e o manejo nutricional das plantas.

A mosca-minadora tem vários predadores que ocorrem de maneira natural no campo, como os parasitoides dos gêneros Diglyphus, Chrysocharis e Halticoptera, e predadores de pupas, como as aranhas e as formigas. Desse modo, é de grande importância que toda medida de controle utilizada possa considerar a preservação desses inimigos naturais.

O controle químico é o método mais utilizado e considerado mais eficiente em altas infestações. Entre os inseticidas recomendados estão os dos grupos químicos piretroides, avermectinas e espinosinas, sendo estes os mais utilizados no controle de Liriomyza spp. 


\subsection{Lagarta-rosca (Agrotis ipsilon)}

A lagarta-rosca, Agrotis ipsilon (Lepidoptera; Noctuidae), é uma praga polífaga, atacando diversos hospedeiros, entre eles, diversas olerícolas, como as pertencentes às famílias retratadas neste capítulo.

Os danos causados por essa praga ocorrem quando ela se encontra no período larval, em que lagartas cortam as plantas rente ao solo, quando estas apresentam até $10 \mathrm{~cm}$ de altura. Os prejuízos se tornam maiores quando há hospedeiros alternativos na área, como outras culturas e/ou plantas daninhas, o que favorece o aumento da população no período anterior ao plantio da cultura.

Os adultos são mariposas que medem de $35 \mathrm{~mm}$ a $50 \mathrm{~mm}$ de envergadura, com asas anteriores marrons com algumas manchas pretas e asas posteriores semitransparentes. A diferença entre machos e fêmeas está nas antenas, sendo as antenas dos machos plumosas e das fêmeas filiformes. As fêmeas têm hábito noturno e, nesse período, realizam a postura dos ovos em rachaduras do solo, sobre plântulas e matéria orgânica no solo próximo à planta hospedeira. Cada fêmea tem capacidade de ovopositar cerca de 600 a 1.000 ovos.

Os ovos permanecem em fase de incubação por um período médio de 5 dias, apresentando coloração amarelo-esbranquiçados e, conforme se passam os dias, tornam-se mais escuros. As lagartas possuem coloração pardo-acizentada escura a marrom-escura, podem atingir de 45 $\mathrm{mm}$ a $50 \mathrm{~mm}$. Apresentam a sutura epicranial na forma de Y invertido. As lagartas têm hábitos noturnos e, durante o dia, encontram-se na base da planta, protegidas sob torrões, ou a poucos centímetros de profundidade no solo, na posição de rosca, o que dificulta o controle nesta fase. A fase de lagarta dura em média 28 dias. A câmara pupal, de coloração marrom a preta, possui entre $17 \mathrm{~mm}$ a $25 \mathrm{~mm}$ de comprimento e é construída pelas lagartas no solo. A fase de pupa dura em torno de 15 dias.

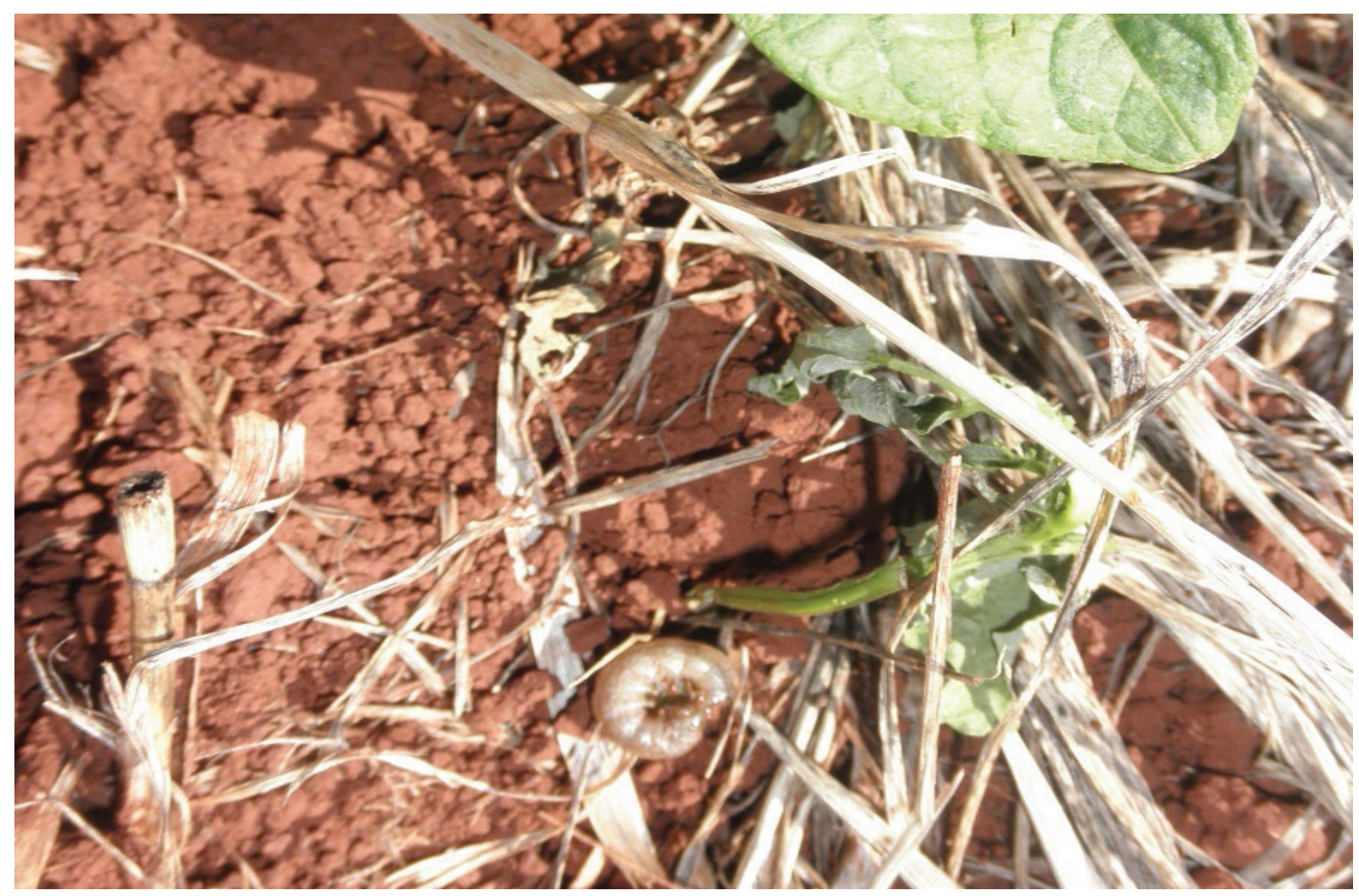

Figura 5 - Ataque de lagarta-rosca.

Fonte: Os autores. 
O controle consiste da união de diversos métodos integrados, preservando, ao máximo, o equilíbrio do ambiente. Inicialmente, indica-se realizar o bom preparo do solo e a eliminação das plantas hospedeiras. $\mathrm{O}$ ataque severo da lagarta-rosca está relacionado com a cultura anterior e com o histórico da área, bem como com a utilização de práticas culturais inadequadas. $\mathrm{O}$ manejo antecipado (rolagem com rolo-faca) das plantas de cobertura e das plantas infestantes é a forma mais promissora de controlar essa praga, pois evita que as lagartas permaneçam na área.

Em áreas com histórico de infestação severa, deve-se evitar o uso de cobertura morta, restos culturais e restos de capina no cultivo. Esses materiais oferecem abrigo às lagartas, protegendo-as de eventuais predadores e das medidas de controle adotadas.

Em relação ao controle químico, há algumas moléculas registradas para solanáceas, como Clorantraniliprole para a cultura do tomate e Clorpirifós para a batata.

\subsection{Vaquinha - Diabrotica speciosa}

Diabrotica speciosa é um coleóptero fitófago, com ocorrência em todo o Brasil e em alguns países da América do Sul. Tem grande importância para a agricultura pelo seu hábito polífago em culturas produtoras de alimentos com elevado valor econômico, como leguminosas, gramíneas, solanáceas e cucurbitáceas.

No caso das cucurbitáceas, assume grande importância econômica, por danificar as plantas desde sua germinação até a época de colheita dos frutos. Os adultos consomem as folhas da abóbora, da abobrinha, da moranga e da melancia, deixando orifícios típicos de seu ataque, além de atuarem como vetores de algumas viroses nessas culturas. As vaquinhas são as pragas mais importantes das cucurbitáceas e, quando atacam as plântulas, podem causar sua morte.

Dentre as razões para o ataque dessa praga sobre as cucurbitáceas, é que plantas desse gênero são caracterizadas pela biossíntese de um grupo de mais de 20 triterpenoides tetracíclicos oxigenados, as cucurbitacinas, extremamente amargas ao paladar e facilmente detectadas por espécies do gênero Diabrotica.

No feijão-de-vagem, os danos mais severos são causados pelos adultos, já que ocorrem quando as plantas iniciam a emissão de folhas primárias, fase caracterizada pela pequena disponibilidade foliar. Estima-se que o consumo foliar médio de D. speciosa é de $0,70 \mathrm{~cm}^{2}$ por dia, podendo atingir $10,32 \mathrm{~cm}^{2}$ até o final do estádio adulto. Mais de dois adultos por planta, na primeira semana após a emergência, causam perdas acima de 50\% na produção, podendo causar a morte da planta.

A vaquinha, quando adulto, é um besouro de $5,5 \mathrm{~mm}$ a $7,3 \mathrm{~mm}$ de comprimento, geralmente de coloração verde e manchas amarelas, o que lhe confere o nome popular de brasileirinho. Os ovos têm formato ovoide, medindo em média de $0,74 \mathrm{~mm}$ a $0,36 \mathrm{~mm}$, com cor variando de branco a amarelo pálido. A fase larval consiste em 3 ínstares, podendo atingir até $12 \mathrm{~mm}$ de comprimento e $1 \mathrm{~mm}$ de diâmetro, sendo seu formato vermiforme, com cabeça e extremidade do abdômen de coloração preta e restante do corpo esbranquiçado. A fase de pupa é caraterizada por sua coloração branca, formato oval e mede cerca de $6 \mathrm{~mm}$.

A duração de cada fase de vida é diretamente influenciada pelo ambiente, apresentando condições ideais ou não a seu desenvolvimento, e também pela planta hospedeira, sendo as plantas de feijão um substrato que permite que essa praga produza até seis vezes mais ovos do que quando se alimenta de milho, por exemplo. 


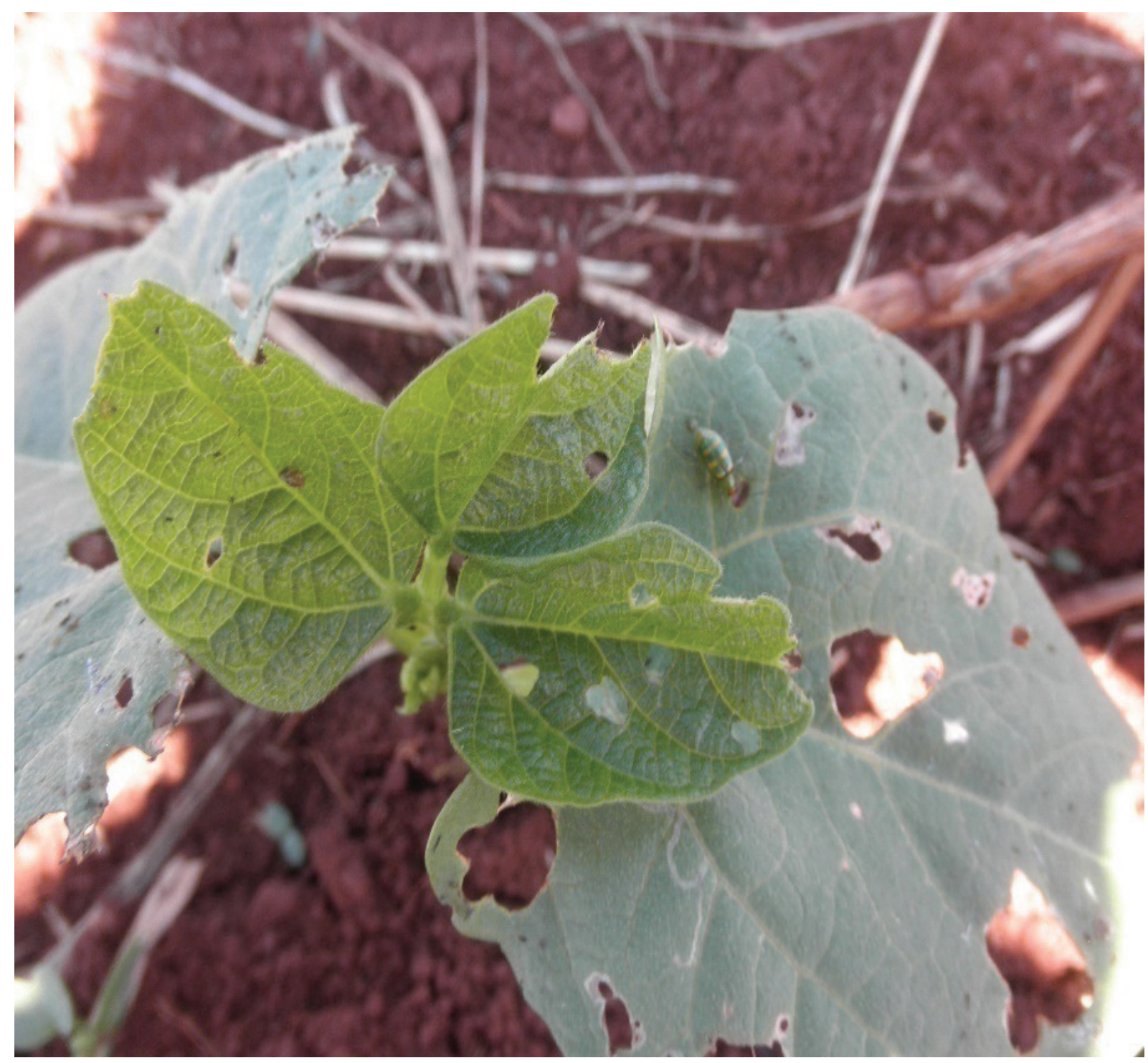

Figura 6 - Ataque de Diabrotica speciosa na cultura do feijão-vagem.

Fonte: Os autores.

Para ovopositar, a fêmea de $D$. speciosa prefere solos com alto teor de argila, matéria orgânica e umidade, o que confere maior índice de sobrevivência das larvas. Em relação ao período de incubação dos ovos, o fator de maior importância é a temperatura, sendo que Milanez e Parra (2000) observaram um período de incubação de 19,6 dias em temperatura média de $18^{\circ} \mathrm{C}$ e 5,7 dias em $32{ }^{\circ} \mathrm{C}$. A temperatura interfere ainda na duração do período larval, que pode ser completo em até 18 dias sobre temperaturas médias de $25^{\circ} \mathrm{C}$, e sobre a mesma temperatura, o período pupal tem duração de até 6 dias, seguido de um período de 3 a 5 dias de duração em que adultos recémformados permanecem dentro da célula pupal para finalização da cutícula. $O$ adulto da $D$. speciosa podem viver de 40 a 50 dias.

O controle de $D$. speciosa se dá principalmente através do controle químico com ingredientes ativos, como tiametoxam e imidacloprido, a partir do momento da constatação do início do ataque da praga na lavoura.

Em conjunto a esse método, podem-se utilizar armadilhas luminosas para o controle de adultos, como também uso de iscas atrativas utilizando partes de plantas das espécies Lagenaria vulgaris ou Cerathosantes hilaria com inseticidas. 


\section{Solanáceas}

\section{1 Ácaros}

\section{Ácaro-do-bronzeamento (Aculops lycopersici (Massee, 1973))}

Esta espécie em especial tem como principais plantas hospedeiras as da família das solanáceas, como o tomate. Como resultado de sua alimentação (sucção de seiva), as folhas e a parte basal das hastes dos tomateiros apresentam bronzeamento de cor escura e aspecto oleoso (brilhante), que evolui para necrose, causando assim a queda das folhas, culminando em frutos não desenvolvidos e com tegumento áspero.

O ácaro-do-bronzeamento no tomateiro pode causar sérios prejuízos, principalmente quando seu ataque ocorre em plantas jovens, podendo chegar a $65 \%$ de perda em plantas recém-transplantadas. Essa praga ocorre em todo o ciclo da cultura, especialmente em temperaturas de em torno $27^{\circ} \mathrm{C} \mathrm{e}$ umidade relativa de $30 \%$. A sua dispersão é realizada principalmente pelo vento.

O ciclo de vida dessa espécie é dividido em três fases: ovo, larva com dois estádios ninfal e adulto, levando ao todo em torno de 6 dias para ser completado sob condições climáticas ideais. Os ovos possuem o tamanho de $0,02 \mathrm{~mm}$, cor branca e formato arredondado e seu período de incubação leva de 2 a 3 dias. Ácaros têm dois estágios de ninfas, ninfa de primeiro estágio e ninfa de segundo estágio. No seu primeiro estágio ninfal, apresenta coloração branca transparente e mede cerca de $0,1 \mathrm{~mm}$. Eles tendem a evoluir para o segundo estágio em um único dia, mantendo a mesma aparência.

As fêmeas adultas são o ínstar mais abundante e frequentemente encontrado em plantas sintomáticas. O corpo é fusiforme, de $0,15 \mathrm{~mm}$ a $0,2 \mathrm{~mm}$ de comprimento, de cor branco-leitosa. Possuem dois pares de pernas de coloração amarelo-alaranjada e estruturas distintas na forma de garra no terminal nos tarsos, chamados de garras de pena, com quatro pares de raios. Esses ácaros não são visíveis a olho nu, sendo assim necessária uma lupa de pelo menos 10 vezes de aumento.

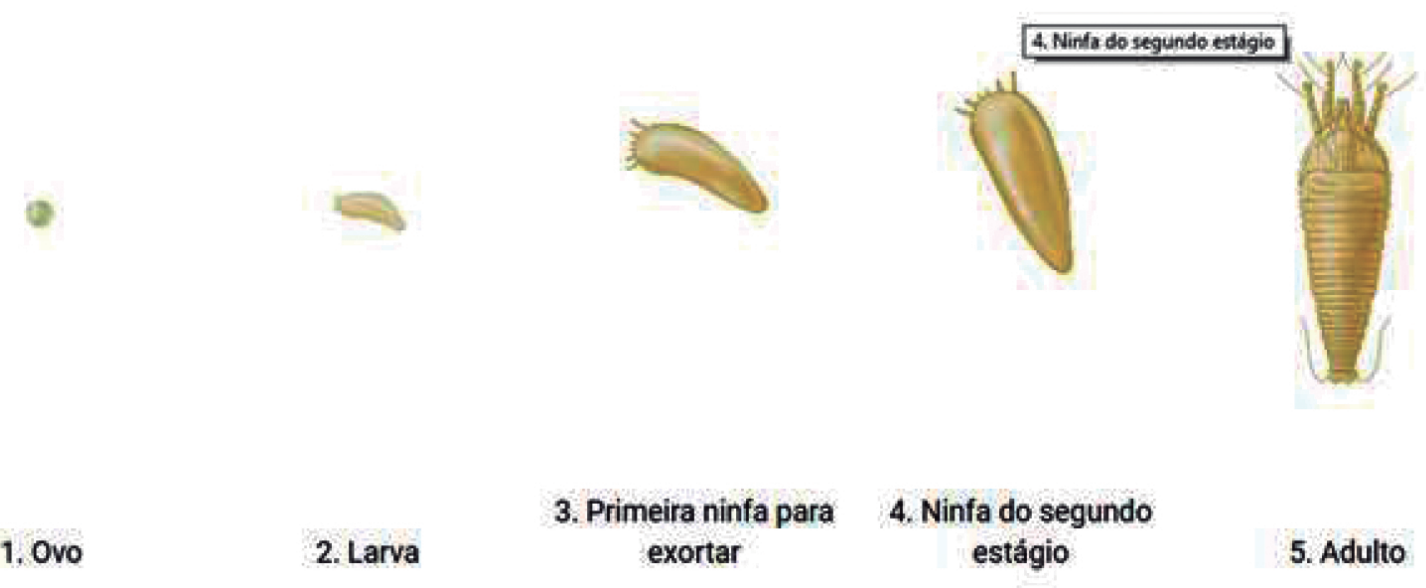

Figura 7 - Ciclo biológico do Ácaro do Bronzeamento.

Fonte: Koppert Biological Systems (2018).

\section{Ácaro-branco (Polyphagotarsonemus latus)}

Os adultos do ácaro-branco apresentam coloração que varia de branca, âmbar ou verde-claro com tegumento brilhante. Há diferenças morfológicas entre machos e fêmeas: os machos medem 
em torno de $0,14 \mathrm{~mm}$ de comprimento e $0,08 \mathrm{~mm}$ de largura, têm o quarto par de pernas muito avantajado, o que lhes permitem carregar a 'pupa' da fêmea, para que, no momento da emergência, a cópula seja garantida; já as fêmeas medem cerca de $0,17 \mathrm{~mm}$ de comprimento e $0,11 \mathrm{~mm}$ de largura. Eles também apresentam ciclos de vida diferentes quando pensamos em dias: os machos, em média, completam seu ciclo em 7 dias e as fêmeas em até 15 dias.

Os ovos são colocados isoladamente na face inferior das folhas novas, têm formato achatado com saliências superficiais e coloração branca. Estima-se que cada fêmea ovoposita até 48 ovos na face inferior das folhas.

Inicialmente, o ataque é concentrado nas folhas dos ponteiros, ocorrendo em reboleira, ficando as folhas com as bordas dos folíolos enrolados para cima, apresentando coloração verde-escura brilhante. Posteriormente, a face inferior do folíolo torna-se bronzeada, pela morte dos tecidos, e as folhas ficam ressecadas e quebradiças.

\section{Ácaro-rajado (Tetranhychus urticae)}

O ácaro rajado ocorre em vários países em diferentes regiões do mundo. Trata-se de uma multivoltino, ocorrendo ao longo de todo o ano, com maiores densidades nos períodos mais quente e secos em cultura de grande importância na olericultura, na fruticultura, na floricultura e em cultivos de fabáceas, como soja e feijão.

$\mathrm{O}$ adulto tem coloração esverdeada com duas manchas mais escuras no dorso, sendo uma de cada lado; as fêmeas medem cerca de $0,5 \mathrm{~mm}$ de comprimento e têm formato ovalado, e os machos em torno de $0,3 \mathrm{~mm}$ com a extremidade posterior do abdômen mais estreita. Cada fêmea coloca de 77 a 134 ovos, esféricos e de tonalidade amarelada.

As larvas são de coloração verde-clara e, com o decorrer do tempo, tornam-se verde-escuro. A fase larval passa por três ínstares e tem duração de cerca de oito dias. Os adultos e as ninfas escarificam o tecido vegetal e alimentam-se da seiva que é extravasada.

As larvas e os adultos vivem na face inferior das folhas, geralmente na parte mediana da planta, onde tecem teias nas quais realizam a postura dos ovos, fixam formas quiescentes e fezes, e também as usam para auxiliar na proteção contra predadores e dispersão entre plantas.

\section{Controle}

Os ácaros da espécie Tetranhychus urticae podem ser controlados biologicamente usando os ácaros predadores Phytoseiulus persimilis ou Neoseiulus californicus.

O ácaro P. macropilis é especialista quanto ao hábito de alimentar-se exclusivamente de ácaros pertencentes ao gênero Tetranychus. Os ácaros especialistas reproduzem-se mais rapidamente do que os generalistas quando a disponibilidade de alimento é elevada. Quando a densidade populacional do ácaro rajado é baixa, $P$. macropilis normalmente se dispersa para fora da área de cultivo em busca de grande quantidade de alimento.

Já o $N$. californicus, que é uma espécie generalista, apesar de alimentar-se preferencialmente do ácaro rajado, na ausência desta presa, pode consumir outras fontes de alimentos, tais como pequenos insetos, outras espécies de ácaros fitófagos ou até mesmo pólen. Em altas populações de T. urticae, há formação de grande quantidade de teia, o que afeta a mobilidade dos ácaros $N$. californicus, prejudicando o controle biológico exercido por essa espécie.

Outros ácaros predadores incluem algumas espécies tolerantes a altas temperaturas ou a pesticidas. Por exemplo, o ácaro predador Amblyseius californicus é relatado para tolerar melhor as condições de seca, enquanto Amblyseius fallacis é resistente a alguns pesticidas. Amblyseius andersoni é outro ácaro predador que tem uma ampla tolerância climática.

Os fungos Beauveria bassiana e Metarhizium anisopliae possuem um grande potencial como agentes para o controle de ácaros-praga, principalmente por serem facilmente produzidos em meios de cultura e sob condições de laboratório. No entanto, para que estes entomopatógenos sejam 
eficientes no controle desses organismos, é necessário que estejam em condições de temperatura e umidade adequadas.

Para o controle químico, há diversos princípios ativos registrados, entretanto o uso de modo equivocado pode contribuir para o desenvolvimento de resistência dos ácaros a esses grupos químicos. Portanto, a partir da constatação da espécie presente na cultura, a aplicação deve obedecer a algumas indicações, tais como aplicação dirigida na face abaxial das folhas onde os ácaros costumam se localizar nas plantas, com pressão e bicos adequados para que os inseticidas de contato tenham maior cobertura e, no caso do ácaro-branco que tece teias, utilizar maior pressão para que o produto penetre nas teias.

\subsection{Traça-do-Tomateiro (Tuta absoluta)}

A traça-do-tomateiro pode ser encontrada nos principais países produtores de tomate da América Latina, ocorrendo durante todo o ano, principalmente no período mais seco. Conseguem sobreviver em plantas voluntárias de tomate e em solanáceas silvestres, como a maria-pretinha (Solanum americanum) ou o joá-bravo (Solanum sisymbriifolium).

A Tuta absoluta (traça-do-tomateiro) pertence à família Gelechiidae, considerada uma das maiores famílias de microlepdópteros e possui como sinonímias Phthorimaea absoluta (MEYRICK, 1917), Gnorimoschema absoluta (CLARKE, 1962), Scrobipalpula absoluta (POVOLNY, 1964) e Scrobipalpuloides absoluta (POVOLNY, 1987).

Em períodos de alta pluviosidade, a população dessa praga encontra-se reduzida, podendo virtualmente desaparecer. Plantações irrigadas por aspersão ou pivô central tendem a ter menores problemas e danos com essa praga, pois a irrigação por aspersão derruba ovos, larvas e pupas, limitando seu potencial de multiplicação. Sua disseminação ocorre através do vento e por frutos atacados contendo as larvas que são comercializados nos centros de distribuição.

Os adultos da traça-do-tomateiro são pequenas mariposas com aproximadamente $10 \mathrm{~mm}$ de envergadura e $6 \mathrm{~mm}$ de comprimento. Sua coloração pode variar entre cinza, marrom ou prateada. As mariposas de Tuta absoluta podem ser vistas ao amanhecer e ao entardecer, momento em que voam, acasalam e fazem a postura dos ovos. As fêmeas podem colocar de 55 a 130 ovos entre 3 a 7 dias.

A ovoposição pode ocorrer nas folhas, nas hastes, nas flores e nos frutos. Geralmente, os ovos são colocados individualmente nas folhas do terço superior da planta, tendo formato elíptico e coloração branca, tornando-se amarelos ou marrons quando próximos da eclosão.

Após a eclosão, que ocorre de três a cinco dias após a postura dos ovos, as larvas penetram imediatamente no parênquima foliar, nos frutos ou no ápice das hastes, pois possuem o hábito alimentar do tipo mastigador. O período larval passa por quatro ínstares e pode durar de oito a dez dias, quando se transformam em pupas. De coloração verde-clara a rosada, as larvas têm como característica uma placa prototorácica preta em forma de meia lua e podem medir de $6 \mathrm{~mm}$ a $9 \mathrm{~mm}$ de comprimento.

Suas pupas são verdes e passam para a cor marrom, e possuem aproximadamente $6 \mathrm{~mm}$ de comprimento. Em sua parte posterior, possui o cremáster com garras de pontas dobradas em forma de gancho, que tem a função de fixar a pupa a uma camada de seda esbranquiçada na planta (folha ou caule) e de facilitar o desprendimento da parte quitinosa, auxiliando assim a saída do inseto adulto. No solo, as larvas podem se esconder debaixo de folhas caídas ou de uma fina camada de terra após secretar substâncias serosas e formar um casulo para se abrigar. Seu ciclo pode durar de 7 a 10 dias. 
O ciclo completo de Tuta absoluta no tomate pode durar de 26 a 30 dias, sendo a longevidade da fêmea de 10 a 15 dias, e do macho de 6 a 7 dias quando adultos.

Os danos são causados pelas larvas, que formam galerias irregulares e transparentes nas folhas para alimentarem-se no interior destas, aumentando em número até sofrerem forte desidratação, ficando necróticas e encarquilhadas.Também atacam as brotações apicais, o caule e os frutos, tornando-os impróprios para a comercialização. Nos locais de ataque, podem ser observadas fezes escuras. Por causa dos ferimentos ocasionados pelas larvas, as plantas podem ser infectadas por patógenos como fungos e bactérias. Quando o ataque é severo, as plantas têm sua capacidade de produção altamente reduzida, ocorrendo a queda dos frutos atacados e a maturação precoce dos frutos que permanecem na planta.
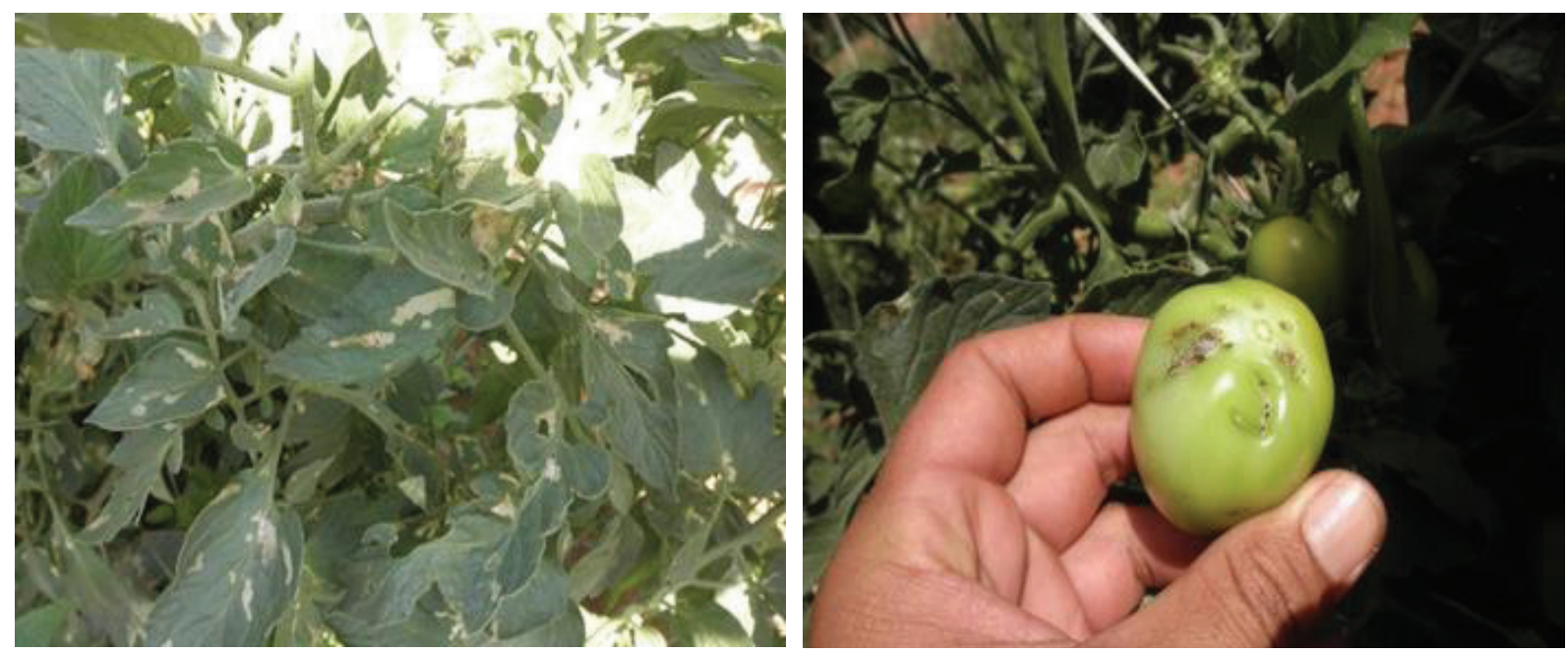

Figura 8 - Ataque de Tuta absoluta nas folhas (Esquerda) e frutos (direita) na cultura do tomate. Fonte: Os autores.

As infestações da traça-do-tomateiro são observadas principalmente durante a fase de frutificação, pois as larvas, por permanecerem dentro dos frutos, não são atingidas pela aplicação de inseticidas, fato esse que facilita a emergência dos insetos adultos e uma nova infestação.

Para a traça-do-tomateiro, o controle cultural consiste na incorporação e na destruição de restos culturais visando interromper o ciclo biológico do inseto, assim como a produção de mudas sadias e a destruição de plantas hospedeiras tendem a auxiliar na redução de infestações.

O controle biológico de Tuta absoluta em tomateiro no Brasil teve seu início em meados de 1990, quando ocorreu um grave surto populacional da praga na região do Submédio São Francisco em 1989, como alternativa de controle que causasse um menor impacto ambiental.

Nas regióes produtoras de tomate onde é utilizado o controle biológico, o nível populacional de Tuta absoluta é relativamente baixo durante o desenvolvimento da cultura. No Brasil, podem ser encontradas doze espécies de parasitoides registrados, como os das famílias Bethylidae, Braconidae, Mymaridae e Trichogrammatidae, além de predadores como vespas, formigas, neurópto Chrysoperla externa (predador voraz de ovos e larvas da traça) e percevejos das famílias Reduviidae, Pentatomidae e Nabidae.

A maior parte do controle biológico se dá pela liberação semanal nas plantações do parasitoide T. pretiosum associada à aplicação do inseticida biológico contendo Bacillus thuringiensis. Para que ocorra a correta utilização de T. pretiosum, a liberação deste parasitoide deve ser realizada 
preventivamente, ou seja, antes de ser verificada a presença da traça na área de produção. Assim, a liberação do parasitoide deve ocorrer entre 20 e 30 dias após o transplante e perdurar por, pelo menos, doze semanas. Outro ponto importante no controle biológico com relação ao inseticida é a seletividade à resistência, sendo recomendado que se faça a rotação com diferentes subespécies de B. thuringiensis, alternando com B. aizawai. Outros micro-organismos têm apresentado resultados satisfatórios no controle da traça-do-tomateiro, como os fungos entomopatogênicos Metarhizium anisopliae e Beauveria bassiana.

Considerando a alta capacidade de reprodução da traça-do-tomateiro, o controle químico ainda é o método mais utilizado no Brasil.

A recomendação é a de que as pulverizações se iniciem tão logo a praga seja encontrada na área. Dessa maneira, a utilização de armadilhas compostas de feromônio ao redor da lavoura pode indicar o momento da chegada do inseto adulto e o momento exato para o início das aplicações.

Com diversos produtos no mercado, a técnica mais correta para o uso de inseticidas é a utilização de um produto por vez e a rotação dos inseticidas de grupos químicos diferentes. No programa de rotação de inseticidas, cada um deve ser utilizado por um período de 28 dias para cobrir aproximadamente uma geração da praga. Se faz necessária a aplicação de, no mínimo, 3 produtos diferentes com o propósito de que uma geração da praga não seja pulverizada com somente 2 produtos diferentes, pois no campo são encontrados todos os estágios do inseto, observando-se, ao mesmo tempo, ovos, larvas, pupas e insetos adultos.

A aplicação de inseticidas piretroides e organofosforados deve ocorrer, preferencialmente, nos períodos de menor atividade dos insetos adultos, garantindo assim que a resistência ocorrerá apenas no estádio larval da praga.

$\mathrm{O}$ inseticida à base de Abamectina é considerado o mais seletivo, apresentando um menor impacto sobre o parasitoide Trichorgramma pretiosum, podendo até $35 \%$ dos ovos da traça-dotomateiro ser parasitados quando esse produto é aplicado.

\subsection{Broca-pequena (Neoleucinodes elegantalis (Guenée, 1984)) Lepdoptera: Crambidae}

A broca-pequena (Neoleucinodes elegantalis) é uma mariposa nativa da região Neotropical e, na América do Sul, é uma importante praga das solanáceas, como Solanum lycopersicum (tomate), Solanum melongena (berinjela), Solanum gilo Raddi (jiló), Capsicum annum (pimentão), e de plantas daninhas, como Solanum palinacathum (juá grande), Solanum reflexus (juá pequeno) e Solanum robustum (jurubeba).

No Brasil, sua ocorrência foi relatada em 1922 no Ceará, em 1939 em São Paulo e, hoje, encontrase disseminada em quase todas as regiões produtoras de tomate no Brasil.

N. elegantalis geralmente ocorre em elevadas infestações, podendo ocasionar mais de $90 \%$ de danos à produção pelas injúrias causadas nos frutos, pressionando o produtor a realizar até duas pulverizações por semana. 


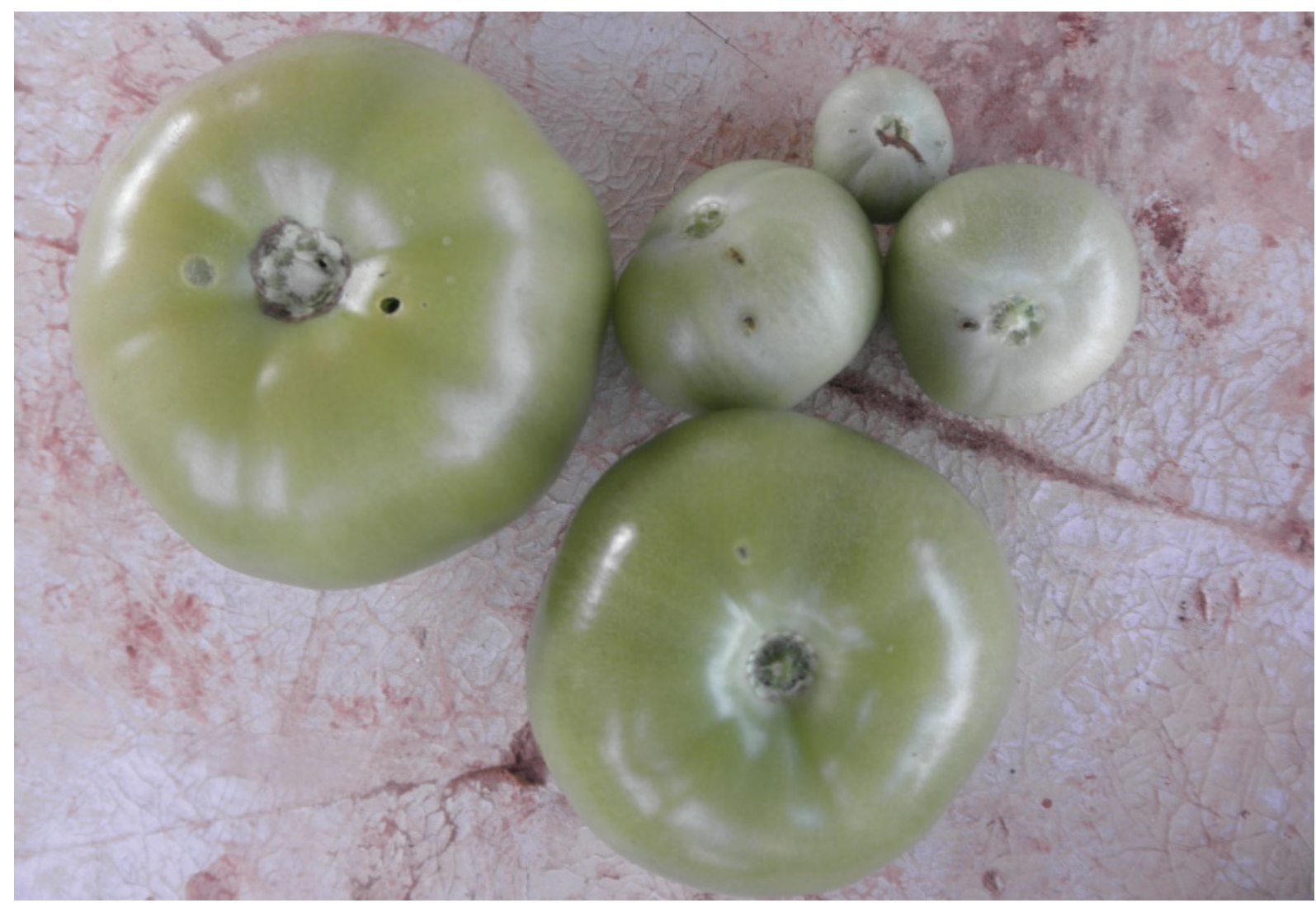

Figura 9 - Danos causados por N. elegantalis na cultura do tomate.

Fonte: Os autores.

N. elegantalis começa a causar danos à cultura quando as fêmeas fertilizadas depositam seus ovos sobre as flores, no pecíolo e nas sépalas, nos frutos verdes e em altas infestações sobre as folhas. Assim que os ovos eclodem, imediatamente as lagartas começam a raspar o epicarpo do fruto em aproximadamente 51 minutos e, em 23 minutos, finalizam sua entrada no interior do mesmo, lá permanecendo protegidas contra a ação de controle. Geralmente, os orifícios de entrada da larva localizam-se $40 \%$ na porção inferior do fruto e esse orifício se fecha, ficando uma lesão quase que imperceptível, a não ser por uma leve protuberância sentida por meio do tato. No interior do fruto, as lagartas alimentam-se do endocarpo (polpa), depreciando comercialmente o fruto.

Antes de iniciar a fase de pupa, a lagarta faz outro orifício no fruto para a sua saída, o qual se torna porta de entrada para microrganismos patogênicos, como fungos e bactérias.

Os adultos da broca-pequena efetuam suas atividades (alimentação, cópula e ovoposição), preferencialmente no período noturno.

As mariposas têm aproximadamente 25 milímetros de envergadura e possuem asas brancas e quase transparentes. As asas anteriores apresentam três manchas irregulares de coloração marrom e, no ápice, uma mancha de cor avermelhada na parte mediana. As asas posteriores apresentam pontos escuros e, no ápice, uma mancha de coloração preta fraca. 0 corpo e as antenas são pardoesbranquiçadas.

As fêmeas de $N$. elegantalis apresentam abdômen volumoso com a parte posterior truncada, e os machos apresentam o abdômen delgado com a parte posterior aguda e recoberta por um penacho em forma de pincel.

O ovo apresenta coloração branco-leitoso quando recém-colocado, passando para amareloclaro, alaranjado e avermelhado próximo à eclosão. Esses possuem formato achatado e são postos isolados ou agrupados. O comportamento de ovoposiçãoé caracterizado pela forma de 
postura, com aproximadamente 2,9 ovos depositados preferencialmente na superfície das flores, no pecíolo e nas sépalas e nos frutos verdes. A fecundidade das fêmeas está diretamente relacionada à temperatura.

As lagartas recém-eclodidas medem de 11 a 13 milímetros de comprimento e permanecem na superfície dos frutos, raspando-os. Possuem coloração rosada e o primeiro segmento torácico amarelado. Após esse período, localizam o ponto de entrada, preferencialmente na porção medianainferior do fruto, e iniciam a alimentação no epicarpo. Ao término do período larval, cerca de 25 dias, abandonam os frutos através de orifícios de saída localizados em qualquer posição do fruto, passando a fase de pupa no solo, protegidos pelos restos culturais ou pelos detritos presentes próximos à planta.

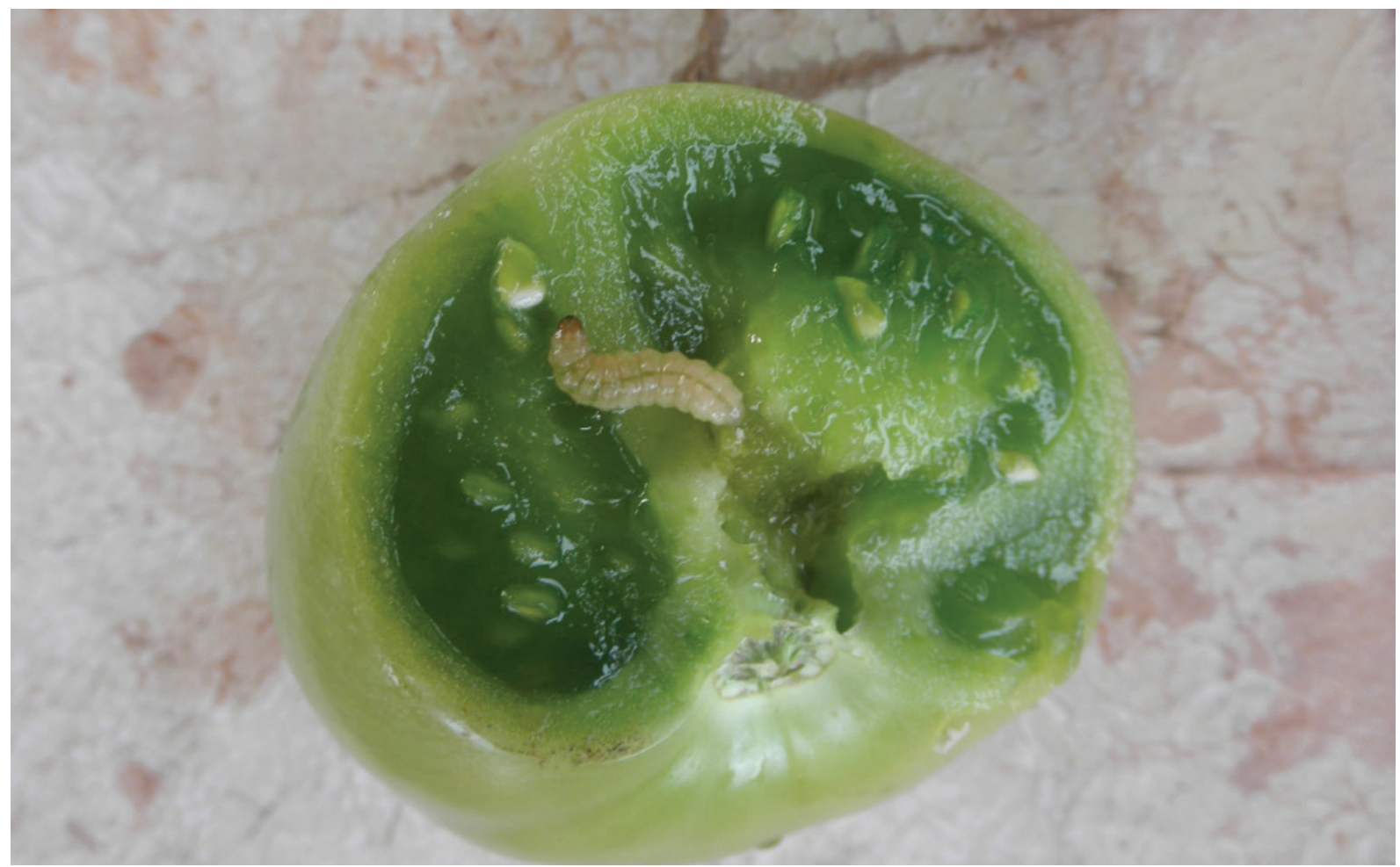

Figura 10 - Fase larval de N. elegantalis dentro do fruto do tomateiro.

Fonte: Os autores.

O monitoramento é essencial para a tomada de decisão de quando e como controlar a praga.

O manejo de Neoleucinodes elegantalis deve ser implantado antes mesmo do transplantio das mudas, evitando-se o escalonamento de plantio e destruindo-se os restos culturais de plantas hospedeiras. Em cultivo protegido, o uso de telas evita a entrada do adulto. É recomendada a divisão da lavoura em talhões de um hectare, onde será feita inspeção de 60 plantas, em 12 pontos casualizados, duas vezes por semana. É recomendado avaliar visualmente as pencas nas plantas contendo frutos em fase inicial de desenvolvimento (diâmetro médio de 2,0 centímetros). Assim, tem-se a vantagem da facilidade de observação das posturas na superfície dos frutos para a constatação de ovos através das amostragens, sendo o nível de controle de 5\% de pencas com ovos, permitindo a tomada de decisão de controle na fase inicial de maior suscetibilidade da praga.

Tratando-se de controle cultural para a broca-pequena, recomendam-se a realização da catação manual e a destruição dos frutos perfurados, a eliminação de solanáceas silvestres e a podadura 
dos brotos terminais quando a planta apresentar de 7 a 8 pencas (55 dias aproximadamente, após o transplante). A utilização de espaçamento maior entre plantas em tomate estaqueado facilita as pulverizações, aumentando a eficiência do produto aplicado.

O controle biológico de $N$. elegantalis pode ser realizado com a utilização do uso de parasitoides do gênero Trichogramma. A libração inundativa de Trichogramma pretiosum em conjunto com amostragens duas vezes por semana é considerada uma medida de controle muito promissora. Por meio das amostragens, pode ser tomada a decisão de indicar ou não a associação de outras medidas de controle.

Os feromônios são substâncias químicas voláteis de ação intraespecífica, utilizados na comunicação dos insetos e podem ser classificados com o tipo de ação que provocam no indivíduo receptor da mensagem. Um dos mais conhecidos é o feromônio sexual, que a fêmea utiliza com o propósito de atrair o macho para dar início à reprodução. Na cultura do tomate, podem ser utilizados para determinar a migração de adultos de lepidópteros-praga.

A primeira evidência de que a praga pode estar presente na área produtora de tomate é a presença dos insetos adultos, fato que permite o estabelecimento das medidas de controle antes mesmo de ocorrer a penetração das lagartas nos frutos, impedindo assim os danos causados, favorecendo também a eficiência dos inseticidas.

Assim, para que a armadilha de feromônio seja adequada como um método seguro de amostragem da broca-pequena-do-fruto, é necessária a comparação com a infestação da praga nas plantas. Tal procedimento pode ser realizado fazendo-se uma correlação entre o número de insetos capturados e a infestação na planta para que, desse modo, as medidas de controle possam ser tomadas a fim de se evitarem ou reduzirem danos. Entretanto essa relação ainda não foi determinada cientificamente para definir uma medida de controle exata.

O controle químico é o método mais utilizado; mas, na maioria das vezes, é ineficaz contra a broca-pequena-do-tomateiro, devido ao comportamento da praga, cuja larva permanece a maior parte do seu ciclo no interior dos frutos.

Dentre alguns produtos químicos utilizados, encontramos os ingredientes ativos flubendiamida, ciantraniliprole, lambda-cialotrina, triflumuron, diflubenzuron. Para a utilização dos produtos, fazse necessário o monitoramento prévio, como mencionado.

A associação dos controles biológico e químico tem sido considerada uma ferramenta altamente eficaz, desde que haja em conjunto o monitoramento. O controle químico seletivo tem como objetivo a preservação do parasitoide Trichogramma pretiosum (Hiley) (Hymenoptera: Trichogrammatidae), utilizado como controle biológico contra $N$. elegantalis.

\subsection{Broca-grande-do-tomate (Helicoverpa armigera, Helicoverpa zea (Boddie, 1850))}

Helicoverpa armigera ocorre geralmente como praga primária em toda a África, no Oriente Médio, no Sul da Europa, na Índia, na Ásia Central e no Sudeste asiático, no Leste e Norte da Austrália, na Nova Zelândia e em muitas ilhas do Pacífico Oriental.

Já H. zea ocorre tanto na América do Norte quanto na América do Sul, com populações permanentes na maioria das áreas entre a latitude $40^{\circ} \mathrm{Ne} 40^{\circ} \mathrm{S}$.

Essas espécies são altamente polífagas e atacam coletivamente uma ampla variedade de culturas, em destaque as que produzem fibras, óleo, forragem, bem como muitas culturas hortícolas e ornamentais. Em relação às áreas cultivadas, algodão, soja, tabaco e leguminosa são culturas de alto valor cuja maior parte das perdas no campo é de responsabilidade dessas lagartas.

O desenvolvimento bem-sucedido de Helicoverpa spp. ocorre em grandes áreas com culturas como milho, soja e algodão, como praga primária; mas as lagartas também se alimentam 
de muitos vegetais importantes, como feijão-vagem, milho doce e tomate. Plantas daninhas também podem servir de hospedeiros para Helicoverpa spp. A habilidade de Helicoverpa spp. de utilizar uma ampla variedade de hospedeiros silvestres dificulta seu manejo na cultura do tomate, uma das culturas que, quando atacadas pela praga, perde seu valor comercial e econômico.

Estudos indicam que o adulto de Helicoverpa spp. é uma praga migratória, e migrações em massa podem ocorrer em uma única noite a longas distâncias, em uma altitude de até 900 metros e até por centenas de quilômetros. Tal fenômeno é explicado pela necessidade de alimentar-se, pela busca de parceiros para a reprodução ou pela procura de locais para a ovoposição.

\section{Helicoverpa zea}

O desenvolvimento da broca-grande é do tipo holometabólico e o ciclo biológico pode variar de 35 a 45 dias.

Os adultos medem de 20 a 25 milímetros de comprimento e chegam a 40 milímetros de envergadura. Possuem asas anteriores de coloração amarelo a parda, com uma faixa transversal mais escura, além de possuírem manchas escuras dispersas sobre as asas. As asas posteriores são mais claras, apresentando uma faixa nas bordas externas. Uma fêmea pode colocar cerca de 1.000 ovos por um período de vida que pode variar de 12 a 15 dias.

Os ovos medem aproximadamente 1 milímetro de diâmetro, apresenta coloração de branca a amarela, com saliências laterais e formato hemisférico, e quando estão próximos à eclosão, passam para uma coloração mais escura, provavelmente devido à cor da cápsula cefálica da lagarta que é quase preta. As posturas são feitas de forma isolada, em diversas partes da planta, e apresentam um período de incubação que pode variar de 3 a 5 dias.

O ciclo larval tem duração de 13 a 25 dias e, nesse período, passa por cinco ínstares. As lagartas apresentam cápsula cefálica marrom e corpo de coloração esbranquiçada a verde-escuro, com faixas longitudinais escuras e manchas pretas. Nos primeiros ínstares, as lagartas possuem um comprimento de 1 a 2 milímetros e, quando completamente desenvolvidas, no quinto ínstar, pode chegar a até 50 milímetros de comprimento.

Após o final do período larval, descem ao solo, próximo à planta, e tornam-se pupas, permanecendo no solo e/ou enterradas sob os restos culturais. Elas possuem coloração marrom brilhante e o período de pupa varia entre 13 a 15 dias.

Os danos causados nas solanáceas são inicialmente cicatrizes visualizadas na epiderme do fruto, quando as lagartas raspam para iniciar a penetração nos frutos. Outro sintoma característico pode ser observado quando se percebem perfurações grandes e irregulares na polpa, onde o dano é direto nos frutos, o qual fica impróprio para a comercialização. Também tanto $H$. zea quanto $H$. armigera causam danos ao alimentarem-se das folhas mais novas das plantas de tomate.

\section{Helicoverpa armigera}

Os ovos de H. armigera são brancos e, antes da eclosão, sua cor torna-se entre amarelada e acastanhada. Na temperatura ideal, a eclosão das larvas pode ocorrer em menos de 3 dias.

Nos primeiros ínstares, as lagartas possuem coloração verde-pálida; mas, nos últimos ínstares, podem ser de variadas cores (de verde-amarelado a castanho-escuro). Elas podem crescer até 40 milímetros de comprimento.

As lagartas podem passar por quatro ou cinco ínstares durante um período de três a quatro semanas. Caracterizam-se por serem alimentadoras vorazes, ocasionalmente carnívoras de outros insetos menores e, às vezes, até canibais. Alimentam-se de folhas, botões florais e flores, frutos e sementes. 


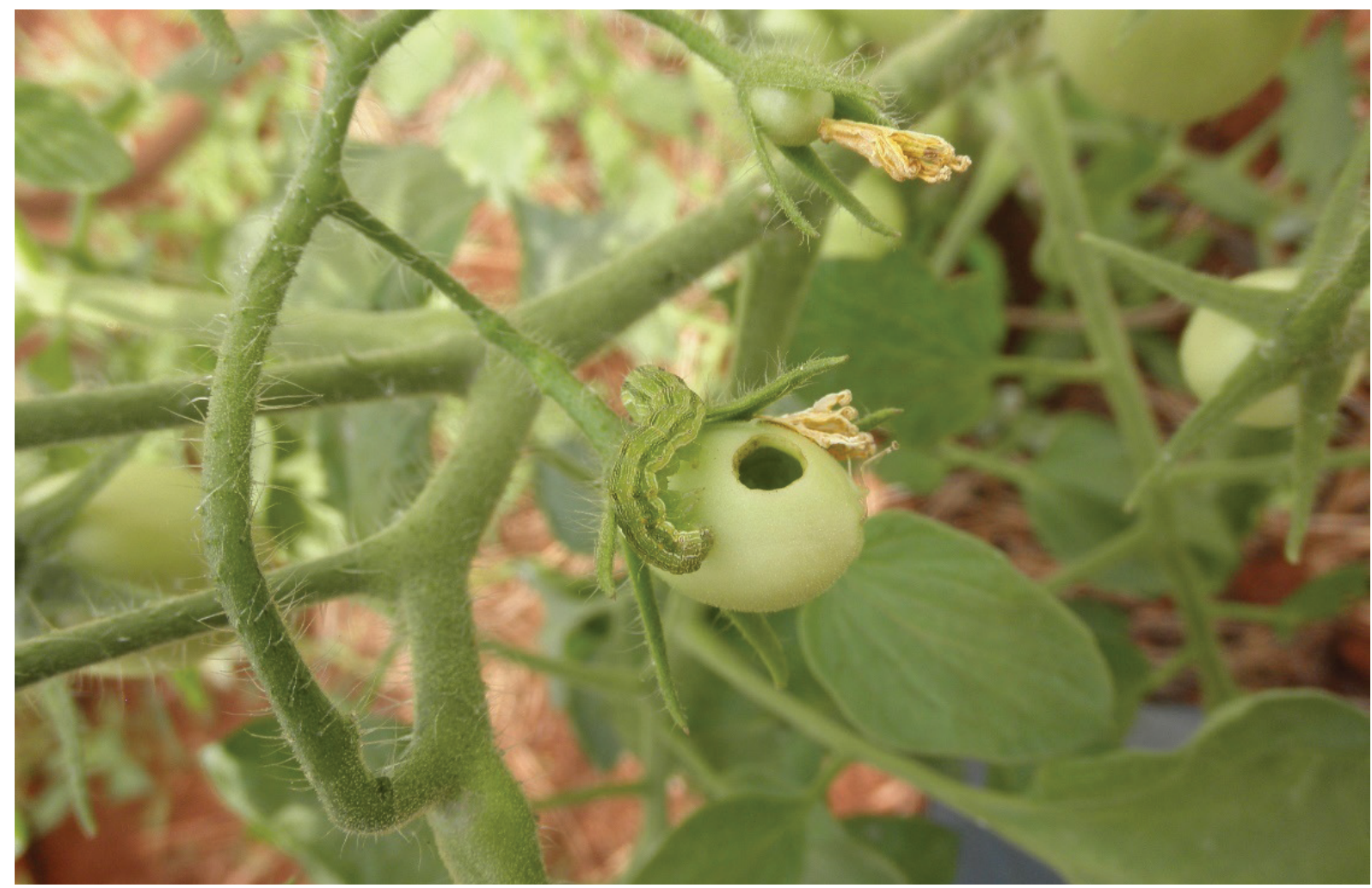

Figura 11 - Helicoverpa armigera na cultura do tomate e dano causado nos frutos.

Fonte: Os autores.

Durante o ínstar final, as lagartas se dirigem para o solo na forma de pupa, geralmente próximo da planta, onde completam seu desenvolvimento. Cavam um túnel que tem aproximadamente 10 centímetros de profundidade e passam por fase de empupação. Nesse estágio, sofrem metamorfose e finalmente emergem como adultos.

Em temperaturas mais altas, a maturação das pupas pode levar até 16 dias e, quando as temperaturas caem, essas entram em diapausa e passam o período na forma de pupa, entretanto essas pupas não suportam geadas severas.

Nas condições ideais e favoráveis para $H$. armigera, seu ciclo de vida é concluído em menos de 30 dias. Nas regiões mais quentes, onde as temperaturas não chegam a graus negativos, não ocorre o diapausa, resultando em inúmeras gerações por temporadas, ou seja, a reprodução é contínua ao longo do ano.

Os insetos adultos são mais ativos à noite (noturnos). A envergadura dos adultos pode variar de 30 a 45 milímetros. Nas fêmeas, as asas anteriores são acastanhadas ou marrom-avermelhadas, enquanto nos machos elas são esverdeadas para amarelo ou castanho claro. As asas traseiras são geralmente mais claras, com uma faixa externa larga e escura.

Os adultos alimentam-se exclusivamente de néctar. As fêmeas, 4 dias após a sua emergência como mariposa, começam a liberar feromônios sexuais e o acasalamento ocorre. Fêmeas de $H$. armigera chegam a botar 3.000 mil ovos em um período de 5 dias. Os ovos são postos no escuro, isoladamente ou em cachos, distribuídos em todas as partes das plantas, incluindo nas flores e nos frutos e, por vezes, em hastes e pontos de crescimento. A longevidade dos adultos pode oscilar em 9 dias para os machos e em 11 dias para as fêmeas.

O manejo de Helicoverpa spp. deve ser baseado no monitoramento das plantas de tomate e de outras plantas em torno da plantação, por esta possuir muitos hospedeiros secundários. 
As mariposas geralmente são atraídas pela cor amarela das flores do tomateiro, sendo nessa fase da cultura (florescimento) que as observações devem ser mais acentuadas; o monitoramento recomendado é de duas vezes na semana, principalmente em áreas próximas a plantios de milho.

Como parâmetro para a entrada de controle, tanto para $H$. zea como para $H$. armigera, é recomendada a observação de frutos danificados, com níveis de controle de $1 \%$. No entanto, essa recomendação é válida para áreas de cultivo de variedades de tomate de mesa. No caso de cultivos de variedades que produzem frutos para a indústria, não existem níveis de controle recomendados.

Desse modo, a área poderá ser dividida em talhões e o monitoramento feito no terço superior das plantas, em pelo menos 20 pontos por talhão. Em cada ponto, o ideal é observar, na fase vegetativa, dez folhas completas, contando ovos e lagartas e, na fase reprodutiva, avaliar dez pencas de flores e/ou dez pencas de frutos, também cotando o número de ovos, lagartas e mais os frutos brocados. A constatação de pelo menos $1 \%$ de amostras com ovos, lagartas ou frutos danificados pode ser um indicativo para que medidas de controle sejam colocadas em prática.

Uma outra ação que pode ser integrada é a destruição dos restos culturais e, nos cultivos de tomate de mesa, a retirada dos frutos atacados, enterrando-os de imediato. $\mathrm{O}$ revolvimento do solo visa à interrupção da fase pupal, inviabilizando a emergência dos adultos, pois destrói os túneis de saída da praga.

O controle biológico da broca-grande Helicoverpa spp., assim como a da broca-pequena $N$. elegantalis pode ser realizado com a utilização do uso de parasitoides do gênero Trichogramma. A libração inundativa de Trichogramma pretiosum em conjunto com amostragens duas vezes por semana é considerada uma medida de controle muito promissora. Através das amostragens, pode ser tomada a decisão de indicar ou não a associação de outras medidas de controle.

No mercado, existem alguns inseticidas biológicos à base de Bacillus thuringienses que vêm obtendo resultados satisfatórios quando utilizados em associação a outros métodos para suprimir a praga na produção de tomate.

$\mathrm{O}$ uso de feromônios para broca-grande também se mostra eficaz e segue o mesmo método explanado para a broca-pequena.

Para a variedade de mesa, o ensacamento de frutos nos tomateiros tende a ser uma alternativa viável, visto que, para Helicoverpa spp. bem como para $N$. elegantalis, os resultados obtidos em diversos estudos com essa prática têm proporcionado boa proteção, com frutos de melhor qualidade e livres de resíduos de agrotóxicos.

O controle químico é o método mais utilizado, mas, na maioria das vezes, é ineficaz contra as brocas, devido ao comportamento da praga, visto que a lagarta permanece a maior parte do seu ciclo no interior dos frutos.

Dentre os produtos químicos utilizados para o controle da broca-grande, encontramos diflubenzuron, clorantraniliprole, clorfenapir, indoxacarbe, triflumuron.

Para a utilização dos produtos, faz-se necessário o monitoramento prévio, como já mencionado, e fazer uso desses quando o nível de infestação for igual ou superior a $1 \%$.

A associação do controle biológico e químico tem sido considerada uma ferramenta altamente eficaz, desde que haja em conjunto o monitoramento. $\mathrm{O}$ controle químico seletivo tem como objetivo a preservação do parasitoide Trichogramma pretiosum (Hiley) (Hymenoptera: Trichogrammatidae), utilizado também como controle biológico para N. elegantalis. 


\section{Cucurbitáceas}

\subsection{Broca-das-cucurbitáceas - Diaphania nitidalise Diaphania hyalinata (Lepidoptera: Pyralidae)}

Em regiões de clima tropical e subtropical, as espécies Diaphania nitidalis e Diaphania hyalinata são consideradas pragas-chave na família das Cucurbitáceas, causando injúrias que podem resultar, em alguns casos, em até $100 \%$ de perdas. Essas espécies ocorrem simultaneamente nos cultivos, entretanto apresentam preferências de locais de ataque distintos, sendo que $D$. nitidalis normalmente ataca os frutos abrindo galerias na polpa, inviabilizando a comercialização, mas também pode haver o consumo de folhas nos primeiros ínstares larvais; já D. hyalinata preferencialmente ataca folhas, brotos e flores ao longo dos seus ínstares larvais, reduzindo significativamente a área fotossintética da planta ou, em altas populações, pode causar a desfolha da planta.

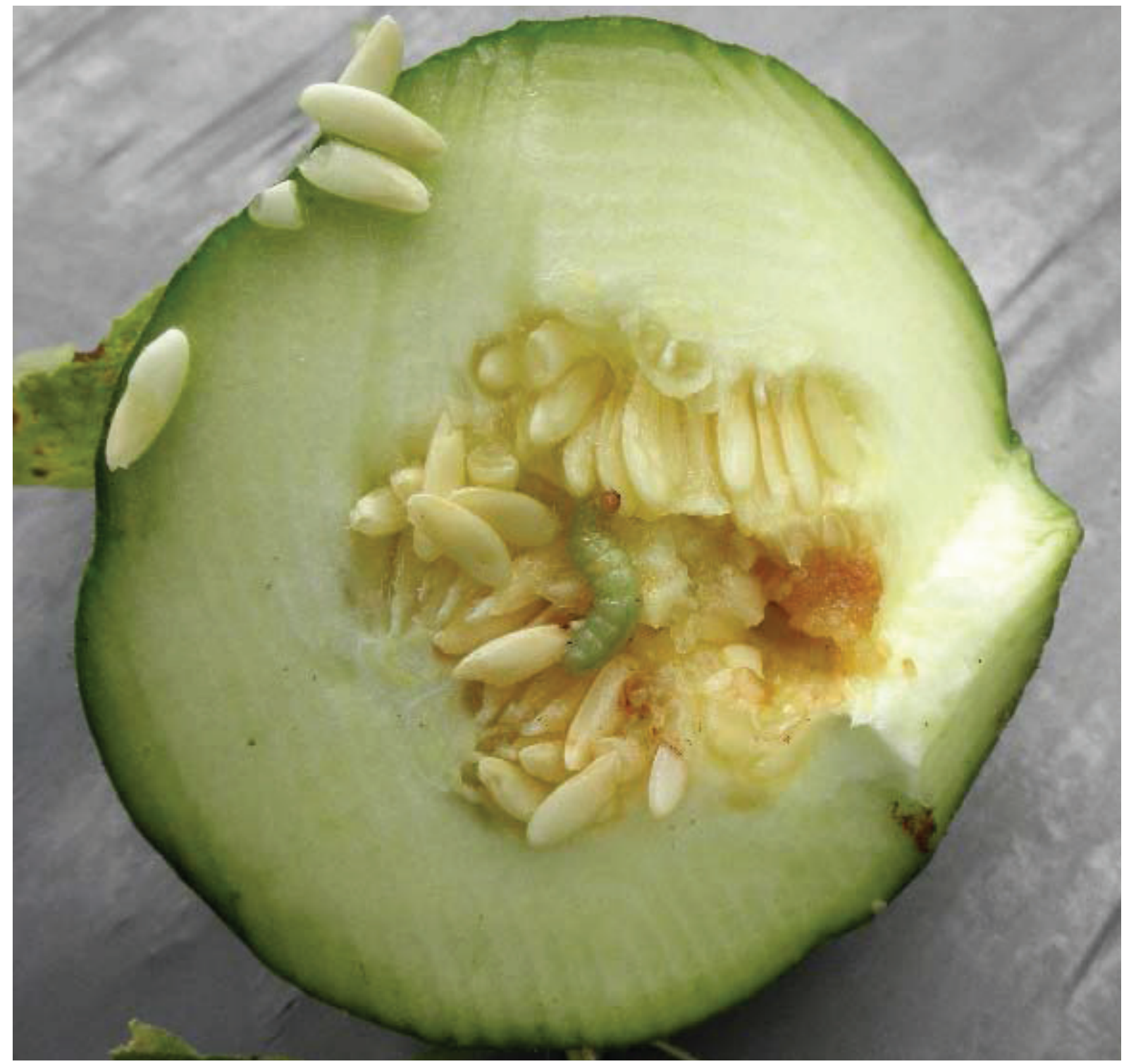

Figura 12 - Diaphania nitidalis na fase larval na cultura do melão.

Fonte: Os autores. 
A espécie Diaphania nitidalis, na fase adulta (mariposa), mede cerca de $30 \mathrm{~mm}$ de envergadura e $15 \mathrm{~mm}$ de comprimento, apresenta coloração marrom violácea e asas com área central amarelada semitransparente e bordos marrom violáceos. Os ovos de formato esférico a achatado, com $0,4 \mathrm{~mm}$ a $0,6 \mathrm{~mm}$ de largura e $0,8 \mathrm{~mm}$ de comprimento, nas primeiras 24 horas, são brancos e, posteriormente, tornam-se amarelos. As lagartas, inicialmente, têm coloração amarelo-esbranquiçada com manchas pretas ou cinzas que desaparecem no quinto e último ínstar, e neste apresentam coloração variável, conforme sua alimentação, e tamanho de até $30 \mathrm{~mm}$ de comprimento. As pupas possuem coloração marrom-escuro e $13 \mathrm{~mm}$ de comprimento, sendo encontradas em folhas secas ou no solo.

Já na espécie Diaphania hyalinata, os adultos são mariposas de coloração marrom-violácea e asas com aéreas semitransparentes, brancas e faixa escura dos bordos mais retilínea. Possui o período larval de 5 ínstares; no primeiro ínstar, as lagartas são incolores; no segundo ínstar, são de coloração amarelo-verde pálida; no quinto ínstar, apresentam coloração verde com duas listras brancas ao longo do dorso e essas listras podem ou não desaparecer antes do desenvolvimento da pupa. A pupa apresenta coloração marrom-claro ou escuro, com $12 \mathrm{~mm}$ a $15 \mathrm{~mm}$ de comprimento e $3 \mathrm{~mm}$ a $4 \mathrm{~mm}$ de largura.

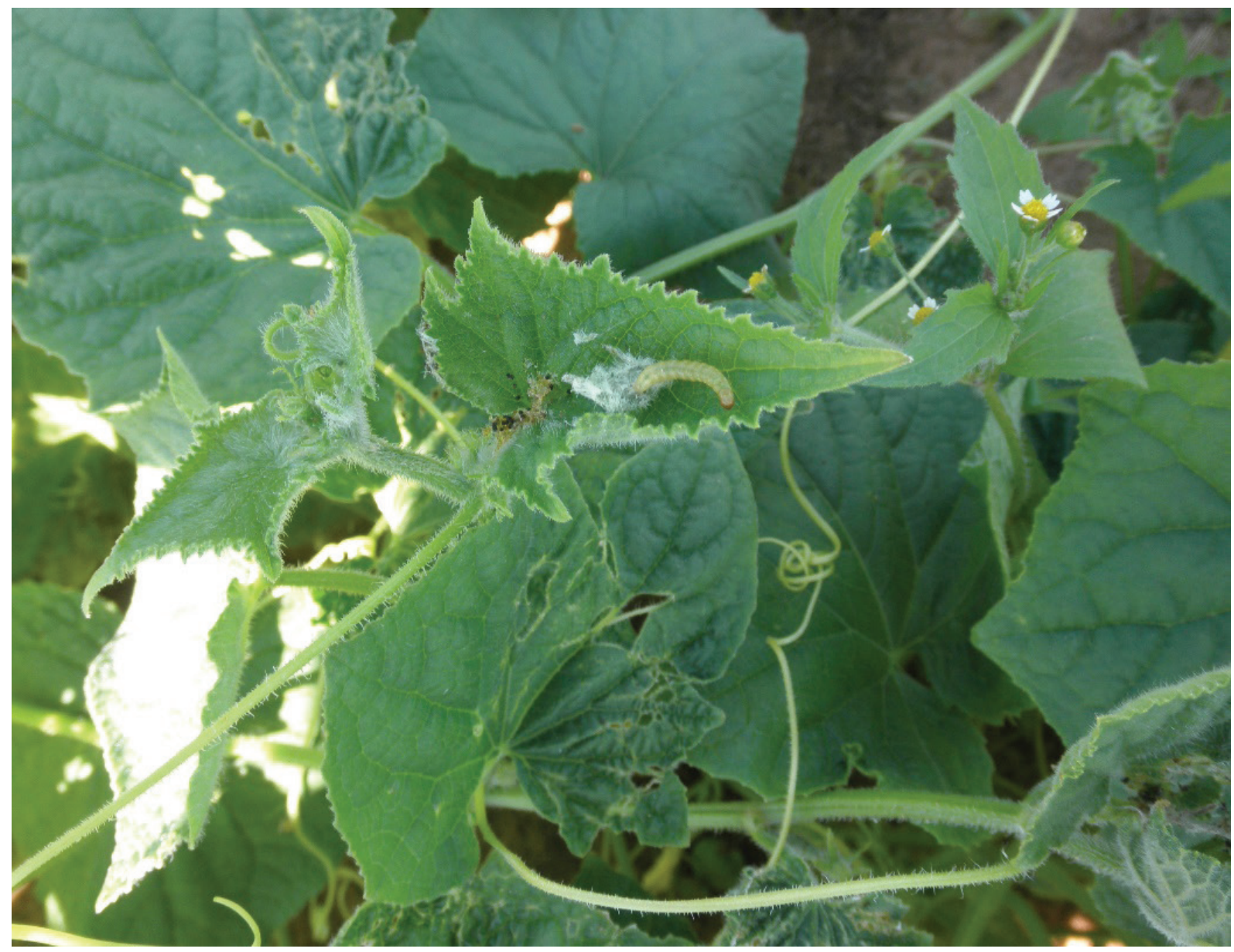

Figura 13 - Diaphania hyalinata em fase larval sobre folhas de pepino.

Fonte: Os autores.

O ciclo de vida das duas espécies é bastante similar em relação ao tempo, mas com algumas diferenças quanto aos hábitos. Em média, para que um ciclo seja completado, são necessários em torno de 30 dias, sendo 3 a 4 dias no período de ovo, seguidos do período larval por 9 a 20 dias, e pupa em média 10 dias. 
Em relação à postura dos ovos, a $D$. nitidalis costuma ovopositar pequenos grupos de ovos em brotos, botões florais e parte em crescimento, enquanto $D$. hyalinata prefere ovopositar grupos de 3 a 8 ovos em brotos, hastes e parte inferior das folhas. Ambas as espécies dificilmente demonstram atividade durante o dia, apenas se forem incomodadas, sendo o período de maior atividade de $D$. nitidalis próximo à meia noite (VALLES; CAPINERA; TEAL, 1991).

Para o controle dessas pragas, o mais comum é o controle químico. Entretanto, quando aplicados inseticidas de contato, e a broca se encontra dentro do fruto, a ação do inseticida se torna menos eficaz.

Dentre as possibilidades de controle biológico, há o uso dos inimigos naturais, como os pertencentes às espécies Crysoperla spp. e a formiga do gênero Paratrechina como predadores de ovos, Trichogramma pretiosum como parasita de ovos e, quando em fase de pupa, o uso de L. coecus.

Em relação ao controle químico, alguns ingredientes ativos, como Deltametrina, Alfacipermetrina+Teflubenzuron e Clorantraniliprole, são registrados para controle das brocas das cucurbitáceas, sendo indicados para casos de início de infestação. A aplicação deve priorizar o recobrimento de toda a parte aérea das plantas, incluindo flores e frutos.

\section{Fabáceas}

\subsection{Cigarrinha-verde (Empoasca sp.)}

A cigarrinha-verde é uma praga de elevada ocorrência nos cultivos de feijão no Brasil, sendo os principais picos populacionais durante o plantio realizado no período da seca, devido à ausência de demais hospedeiros além da cultura do feijão.

Os adultos da cigarrinha-verde são de coloração verde, com $3 \mathrm{~mm}$ de comprimento, sendo a postura endofítica e de preferência realizada ao longo das nervuras das folhas dentro da epiderme, diminuindo assim a suscetibilidade aos fatores externos, com uma média de 60 ovos por fêmea. Os ovos têm tamanho médio de $0,79 \mathrm{~mm}$, com um período de incubação médio de 6 a 8 dias, sobre temperatura média de $25^{\circ} \mathrm{C}$.

As ninfas são menores e de coloração verde mais clara, têm o hábito de se locomover lateralmente, mas tendem a permanecer em um mesmo local, o período larval para ser completo passa por 5 ínstares, entre 8 a 9 dias. 0 ciclo completo dessa praga é de aproximadamente três semanas, sendo os adultos mais atraídos pela cor amarela.

Os sintomas do ataque são semelhantes às viroses. Os danos causados ao feijoeiro, porém, são devidos à ação toxicogênica associada à alimentação da praga, que injeta saliva para a pré-digestão da seiva. O período crítico é quando o ataque ocorre até o florescimento da planta, uma vez que, além do dano direto, provocando o atrofiamento, a mesma poderá atuar como vetor de agentes fitopatogênicos.

A cigarrinha é encontrada na face inferior do folíolo e tanto adultos como ninfas se alimentam sugando seiva, causando o 'enfezamento' da planta, que fica com as bordas dos folíolos voltados para baixo. Em casos mais severos, ocorre o amarelecimento das margens dos folíolos e posterior secamento dessas estruturas, chegando também a causar redução no porte das plantas e, consequentemente, causando redução da produtividade. O nível de controle para a cigarrinhaverde no feijoeiro é de duas ninfas por folíolo.

A literatura a respeito do nível de dano econômico é bastante rara, apesar da grande quantidade de trabalhos que visam avaliar o controle da cigarrinha. Gallo et al. (2002) e Barros et al. (2000) fizeram referência a duas ninfas por folha em 100 plantas examinadas em um hectare. 


\section{Referências}

ARAUJO, E. L. de et al. Técnica de criação da mosca-minadora Liriomyza trifolii (Burgess) (Diptera: Agromyzidae). Campo Digital, Campo Mourão, v. 2, n. 1, 2007.

ARRUDA-GATTI, I. C. de; VENTURA, M. U. Iscas contendo cucurbitacinas para o manejo de Diabrotica spp. Semina: Ciências Agrarias, Londrina, v. 24, n. 2, p. 331-336, 2003.

BALDIN. E. L. L.; LARA, F. M. Atratividade e consumo foliar por adultos de Diabrotica specios (Germ.) (Coleoptera: Chrysomelidae) em diferentes genótipos de abóbora. Neotropical Entomology, Londrina, v. 30, n. 4, p. 675-679, 2001.

BARROS, B. .C et al. Manejo integrado de pragas e doenças do feijoeiro. Campinas: Secretaria de Agricultura e Abastecimento, 2000.

BAVARESCO, A. Efeito de tratamentos químicos alternativos no controle de Diaphania spp. (Lepdoptera: Crambidae) em pepino. Acta Scientiarum Agronomy, Maringá, v. 29, n. 3, p. 309-313, 2007.

BENVENGA, S. R. Neoleucinodes elegantalis (Guenée) (Lep.: Crambidae) em tomateiro estaqueado: dinâmica populacional, nível de controle com feromônio sexual e eficiência de agrotóxicos. 2009. 134 f. Tese (Doutorado)-Programa de pós-graduação Agronomia, Universidade Estadual Paulista, Botucatu, 2009.

et al. Monitoramento da broca-pequena-do-fruto para tomada de decisão de controle em tomateiro estaqueado. Horticultura Brasileira, Brasília, DF, v. 28, p. 435-440, 2010.

BLACKMER, J. L.; EIRAS, A. E.; SOUZA, C. L. M. de. Oviposition preference of Neoleucinodes elegantalis (Guenée) (Lepidoptera: Crambidae) and rates of parasitismo by Trichogramma pretiosum Riley (Hymenoptera: Trichogrammatidae) on Lycopersicon esculentum in São José de Ubá, RJ, Brazil. Neotropical Entomology, Londrina, v. 30, n. 1, p. 89-95, 2001.

BÔAS, G. L. V.; BRANCO, M. C. Manejo integrado da Mosca-branca (Bemisia tabaci biótipo B) em sistema de produção integrada de tomate industria (PITI). Brasília, DF: Embrapa, 2009. (Circular técnica, n.70).

BRITO, G. G. et al. Preferência da broca-das-cucurbitáceas [Diaphania nitidalis Cramer, 1782 (Lepidoptera: Pyralidae)] por cultivares de pepineiro em ambiente protegido. Ciência Rural, Santa Maria, v. 34, n. 2, p. 577-579, 2004.

CARNENO, J. S.; HAJI, F. N. P.; SANTOS, F. A. M. Bioecologia e controle da broca pequena Neoleucinodes elegantalis. Teresina: Embrapa Meio-Norte, Embrapa Meio-Norte, 1998. (Circular técnica, n. 26).

COSTA-LIMA, T. C.; SILVA, A. C.; PARRA, J. R. P. Moscas-minadoras do gênero Liriomyza (Diptera: Agromyzidae): aspectos taxonômicos e biologia. Petrolina: Embrapa Semiárido, 2015. (Documento,v. 268).

DANIEL, L. OLMSTEAD, BRIAN A. NAULT, ANTHONY M. SHELTON; BIOLOGY. Ecology, and evolving management of Helicoverpa zea (Lepidoptera: Noctuidae) in Sweet Corn in the United States. Journal of Economic Entomology, Lanham, v. 109, no. 4, p. 1667-1676, 2006.

FILHO, M. M. et al. Recomendações técnicas para o controle de pragas do pepino. Brasília, DF: Embrapa Hortaliças, 2012. (Circular técnica, n. 109). 
FITT, G. The ecology of heliothis species in relation to agroecosystems. Annual Review of Entomology, Stanford, v. 34, no. 1, p. 17-53, 2003.

FRANÇA, F. H. et al. Manejo integrado de pragas. In: SILVA, J. B. C.; GIORDANO, L. B. (Org.). Tomate para processamento industrial. Brasília, DF: Embrapa Hortaliças, 2009. p. 113-117.

GALLO, D. et al. Entomologia agrícola. Piracicaba: FEALQ, 2002.

GUIMARÃES, J. A. et al. Biologia e manejo de mosca minadora no meloeiro. Brasília, DF: Embrapa, 2009. (Circular técnica, v. 77).

HODGES, A. et al. Pest thrips of the United States: field identification guide. [S.l.]: USDA-CREES Integrated Pest Management Centers, 2009.

JÚNIOR, S. P. et al. Ensaio para o controle químico da broca-pequena Neoleucinodes elegantalis (Guennée 1854) (Pyralidae Lepidoptera) do tomate. Pesquisa Agropecuária Tropical, Goiânia, v. 21-22, n. 1, p. 127-131, 1991-1992.

KOPPERT BIOLOGICAL SYSTEMS. Aculops lycopersici: ácaro del bronceado del tomete. Disponível em: < https://www.koppertus.ms/retos/aranas-rojas-y-otras-aranas/acaro-delbronceado-del-tomate>. Acesso em: 01 nov. 2018.

LABINAS, A. M. Controle de pragas na cultura do feijão (Phaseolus vulgaris L.) e avaliação econômica. 2002. 141 f. Tese (Doutorado)-Programa de Pós-Graduação Agronomia Universidade Estadual Paulista, Botucatu, 2002.

LEITE, M. V. Biologia de AphisgossypiiGlöver, 1877 (Hemiptera: Aphidae) em cultivares de Cucurbita spp. e sua interação com o predador Ceraeochrysa cubana (Hagen, 1861) (Neuroptera: Chrysopidae). Lavras: UFLA, 2006.

LIMA, V. L. S. Manejo fitossanitário para brocas-das-cucurbitáceas Diaphania nitidalis Cramer (Lep.: Crambidae). 2009. Dissertação (Mestrado)-Programa de Pós-Gradaução em Agronomia, Universidade Federal do Espirito Santo, Alegre, 2009.

LYRA NETTO, A. M. C. de; LIMA, A. A. F. Infestação de cultivares de tomateiro por Neoleucinodes elegantalis (Lepidoptera: Pyralidae). Pesquisa Agropecuária Brasileira, Brasília, DF, v. 33, n. 2, p. 221-223, 1998.

MILANEZ, J. M.; PARRA, J. R. P. Biologia e exigências térmicas de Diabrotica speciosa (Germar) (Coleoptera: Chrysomelidae) em laboratório. Anais da Sociedade Entomológica do Brasil, Londrina, v. 29, n. 1, p. 23-29, 2000.

MOURA, A. P. et al. Manejo integrado de pragas do tomateiro para processamento industrial. Brasília: Embrapa Hortaliças, Embrapa Hortaliças. 2014. (Circular técnica, v. 129).

PANTHI, B. R. et al. Host selection, growth, and survival of melon worm (Lepdoptera: Crambiadae) on four cucurbit crops under laboratory conditions. Environmental Entomology, College Park, v. 45, no. 4, p. 945-951, 2016.

PECCHIONI, M. T. D. et al. Aspectos morfologicos y poblaciones de Diabrotica speciosa (Germar) (Coleoptera: Chrysomelidae) em condiciones de laboratório. Anais Sociedade Entomológica do Brasil, Londrina, v. 29, n. 2, p. 285-294, 2000.

PINENT, S. M. J.; CARVALHO, G. S. Ecologia, comportamento e bionomia: Biologia de Frankliniella schultzei (Trybom) (Thysanoptera Thripidae) em tomateiro). Anais Sociedade Entomológicado Brasil, Londrina, v. 27, n. 4, p. 519-524, 1998. 
PRATISSIOLI, D. et al. Desenvolvimento da broca-das-cucurbitaceas em diferentes tipos de substratos alimentares. Horticultura Brasileira, Brasília, DF, v. 25, n. 4, p. 598-601, 2007.

Incidência de mosca-minadora e insetos vetores em sistemas de manejo de pragas em tomateiro. Revista Ciência Agronômica, Fortaleza, v. 46, n. 3, p. 607-614, 2015.

PRIYA, N. G. et al. Host Plant Induced Variation in Gut Bacteria of Helicoverpa armigera. PLoS ONE, San Francisco, v. 7, n. 1, e30768, 2012.

SANTOS, M. D. et al. Eficiência de isolados comerciais de Beauveria bassiana (Bals.) Vuillemin e Metarhizium anisopliae (Metsch.) Sorok (Hypocreales: Cordycipitaceae, Clavicipitaceae) sobre o ácaro rajado Tetranychus urticae Koch (Acari: Tetranychidae). Revista Brasileira de Biociências, Porto Alegre, v. 14, n. 2, p. 76-79, 2016.

VALLES, S. M.; CAPINERA, J. L.; TEAL, P. E. A. 1991. Evaluation of pheromone trap design, height, and efficiency for capture of male Diaphania nitidalis. (Lepidoptera: Pyralidae) in a field cage. Environmental Entomology, College Park, v. 20, p. 1274-1278. 